\title{
THE INDIAN OCEAN
}

THE GEOLOGY OF ITS BORDERING LANDS AND THE CONFIGURATION OF ITS FLOOR

By

James F. Pepper and Gail M. Everhart

MISCELLANEOUS GEOLOGIC INVESTIGATIONS
MAP I-380

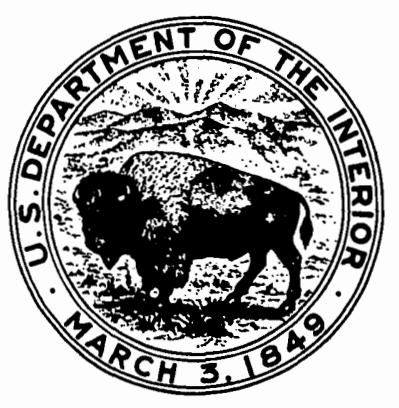

PUBLISHED BY THE U. S. GEOLOGICAL SURVEY

WASHINGTON, D.C. 
THE INDIAN OCE.AN

\section{THE GEOLOGY OF ITS BORDERING LANDS AND THE CONFIGURATION OF ITS FLOOR}

By

James F. Pepper and Gail M. Everhart

\section{INTRODUCTION}

The ocean realm, which covers more than 70 percent of the earth's surface, contains vast areas that have scarcely been touched by exploration. The best known parts of the sea floor lie close to the borders of the continents, where numerous soundings have been charted as an aid to navigation. Yet, within this part of the sea floor, which constitutes a border zone between the coast and the ocean deeps, much more detailed information is needed about the character of the topography and geology. At many places, stratigraphic and structural features on the coast extend offshore, but their relationships to the rocks of the shelf and slope are unknown, and the geology of the coast must be projected seaward across the continental shelf and slope.

The Indian Ocean, the third largest ocean of the world, has been selected for intensive study by an international group using all modern techniques to determine its physical characteristics. This report, with accompanying illustrations, has been prepared as a very generalized account of some aspects of the geology of the vast coastal areas of the northern Indian Ocean in relation to the bordering shelves and ocean deeps. Its general purpose is to serve as background reading.

\section{GEOLOGIC FEATURES OF THE LAND AREA ANCIENT SHIELDS, RIFT SYSTEMS, DEPOSITIONAL AREAS, AND THEIR TECTONIC RELATIONSHIPS}

The basic framework of the lands bordering the northern Indian Ocean consists of three great shield areas, which form a roughly triangular pattern and which are composed predominantly of igneous and metamorphic rocks dating back to Precambrian time. The African shield and its continuation in the Arabian shield lie to the west and northwest, the Indian shield to the north, and the Australian shield to the east. Outside these shield areas but within the Indian Oćean region, highly metamorphosed Archean rocks form a large part of the island of Madagascar (Republic of Malagasy) and of the Shan Hills of eastern Burma.

Patterns of weakness of the earth's crust, believed by some geologists to have originated when the shields were formed, have had marked influence on the subsequent tectonic history of these and marginal areas. The eroded shield areas at many places contain linear patterns or trend lines that mark the effects of ancient crustal forces. The patterns of trend lines or "grain" in the shield areas are closely related to the ancient "ground blocks" of the continent and ocean bottoms as outlined by Cloos (1948), who states: "It seems from early geological time the crust has been divided into polygonal fields or blocks of considerable thickness and solidarity and that this primary division formed and orientated later movements."

Block structures of this kind were noted by Krenkel (1925-38, fig. 4, p. 26), who outlined rigid basins and intervening mobile belts of early age on the African continent. By analogy he traced them into the basins and swells in the Indian Ocean, the whole forming a roughly connected block pattern. Hans Cloos, according to Hills $(1947$, p. 5), reached the same conclusions but noted further that $11 * * *$ the major features of today***even in details are related to the primitive structure.'" Later structures, Hills indicates, "***are preferentially developed parallel to the older, but also secondarily at right angles to them." Thus, two trends were developed, the first, parallel to existing planes of weakness such as folding, foliation, and schistosity, and the second, parallel to trans verse joints and faults in these old structures.

Africa has been referred to by Dixey (1956, p. 50-51) as $" * * *$ a great shield which to a large extent assumed its present limits in the early to mid-Jurassic*** readily divisible into a number of basins separated by swells,minor shields, or plateaux***." He describes heaving of the swells and widespread or "continental" uplift along the swells, accompanied at places by downward movement in the basins, commonly with axes of movement following. Precambrian trends. He also notes that at times movement recurred along cross structures.

The shield area of peninsular India is composed of igneous and metamorphic rocks of Precambrian age, which were much crushed and fractured during Archean time. The peninsula, however, is a stable block that has not been affected by folding since the close of the Precambrian. As a unit it has been affected by upwarps and downwarps, with possibly some tilting to the east. The vertical movements have resulted in normal and block faulting on the margins of the peninsula. Hills (1947, p. 6) notes that the major existing topographic features of the peninsula, including the coastline and its bordering eastern and western 
mountains, are directly related to the grain of the Indian shield.

The western two-thirds of Australia constitutes one of the larger world shields of Precambrian formations, which consist largely of granitic and metamorphic rocks but which include some belts of sedimentary rocks that show little metamorphism. Fairbridge (1950) shows the division of Australia into a series of rather irregular parts--blocks and basins corresponding to major upwarps and downwarps, with platforms and sunklands as lesser units. The major blocks he places mainly in the western two-thirds of the continent and regards as having been subjected to long-continued erosion. Hills $(1947$, p. 5$)$ has determined that the trends or grain of the older Precambrian rocks have exercised control over all later structures.

The structural trends in the three shields and in folds of the bordering areas are shown in a general way in figure 1.

The structural history of the vast region bordering the northern Indian Ocean is complicated by the diversity and intensity of tectonic forces that affected parts of the region during different periods of geologic hisiory. For the most part, structural movements more or less continuous are apparent in the rock sequence from Precambrian to Recent time, but within this great range of time tectonic movements culminated in marked regional deformations at the end of the Paleozoic, during the early and late Mesozoic, and during the Tertiary.

In a general way, vertical and horizontal tectonic forces acting within different geomorphologic divisions of the Indian Ocean borderlands have produced two types of structural features. Upwarping and downdropping along normal faults have been prevalent in the shield areas, producing the rifts of eastern Africa and western Arabia and block-faulted regions in peninsular India and western and southern Australia. Outside the shields, sags or foredeeps formed by downwarping of the crust and later filled with sediments have in some places been subsequently folded and thrust faulted by predominantly horizontal stresses into great regional arcs, as in the Himalayas and the island chain of Indonesia.

The series of fault troughs that traverse the eastern part of the African shield are among the unique structures of the earth's surface. They extend, although not continuously, from the Zambesi River region in Mozambique northward into Abyssinia. They then fork, one branch trending northwestward through the Red Sea and thence northward to Lebanon and northern Palestine, the other trending northeastward from the Red Sea across the Gulf of Aden into the

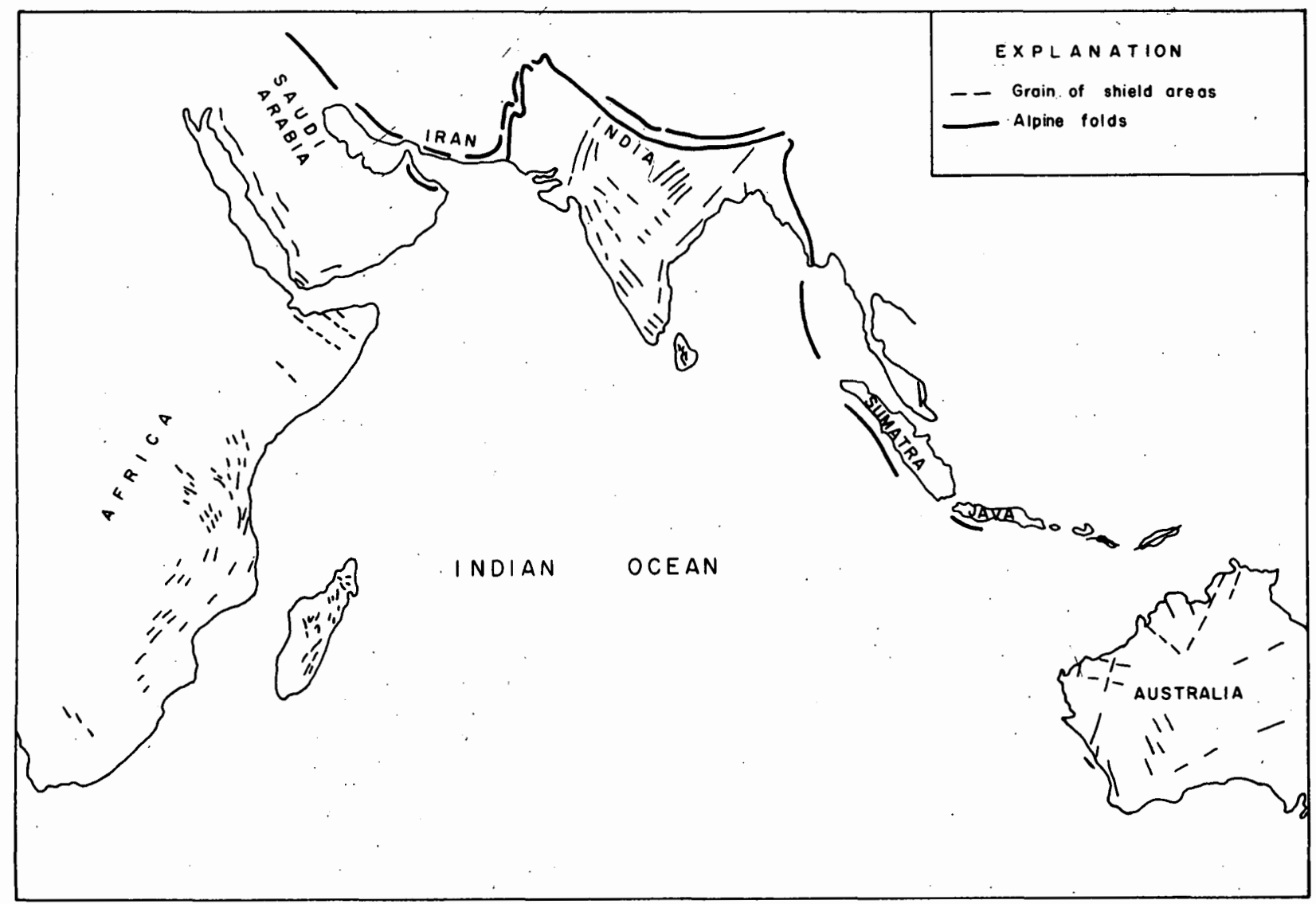

Figure 1.--Diagram showing grain of shield areas in continents bordering the Indian Ocean and the trend of Alpine-type folds from Iran to Java. 
Arabian Sea. They form one of the most extensive fracture systems in the world; the African-Lebanon branch is about 4,000 miles long, or approximately one-sixth of the earth's circumference. The manner in which the deep-seated forces formed the rifts is controversial.

Dixey (1956) thinks there is reason to believe that the rift system is a structure alined along a very early, practically primordial weakness of the crust, which renewed its influence with every readjustment of the crust in subsequent ages. The East and Central African rifts and troughs, he states (p. 57) "***can be regarded as merely branch fractures intersecting the rising rim of Africa, while the Gulf of Aden/Red Sea $r$ ift appears as a relatively youthful marine branch, although again following ancient trends."

The East African rift system was presumed from early mapping to extend southward only a short distance beyond the Zambesi River, but Bettencourt Dias (1956) and particularly Dixey (1956) have noted a relationship between the rift structures and structural features to the south in Mozambique. Bettencourt Dias believes that the southern part of Mozambique east of the faults along its western border represents a block that must have sunk before the eruptions of basalts in late Karroo (Triassic) time. The downwarping of this block, the Lebombo monocline of Dixey (1956), probably caused a hinge line or tension zone along which the basalts of the Lebombo range were extruded, for according to Du Toit (1926, p. 438) they form the western margin of this flexure by which the entire Karroo System was given an easterly tilt and from which early Jurassic lavas dipped beneath the sea.

Dixey (1956, p. 48) regards the Lebombo monocline as 1***one of the major structures of the great system of folds and trough faults into which central and southern Africa was thrown after the end of the Stormberg volcanic episode" of late Karroo time. He draws attention to the close parallelism of features of the Lebombo range and those of earlier structures, particularly those of the Precambrian, and notes that, like the East African rifts, the Lebombo monocline has been uplifted in the Cretaceous, mid-Tertiary, end-Tertiary, and later. He suggests that the monocline and the East African rift bulge are but two parts of one great structure.

From the stratigraphic history, Dixey (1956, p.49) believes that the channel between the African mainland and Madagascar has been sinking over a long period of time--at least since the Permian. In contrast, the eastern highlands of Madagascar and the broad marginal rim of eastern Africa have been areas of intermittent uplift since ancient times. Thus the intervening downwarped ("lag") area of the Mozambique Channel, the western rim of which Dixey suggests may extend along nearly the whole of the eastern side of Africa, has the character of a large geosyncline. The geosyncline he regards as another example of the more complex African rifts, although on a considerably larger scale. He states that "One could go further, and regard the geosyncline as the principal feature in the immense pattern of events that has dominated the whole of this large part of Africa since Permian, or even possibly the later pre-Cambrian, times***In the Tertiary and the post-Tertiary, rift faults powerfully affected the margins of the geosyncline and extended some, but not all, of the major postKarroo fault troughs, and similarly along pre-Cambrian lines of weakness to form the East African rift system."

In summary, Dixey (1956) suggests that the East African rift system can be regarded 1***as the concomitant of the prolonged, but intermittent, development of the Mozambique geosyncline***" which, he states, has the character both of a subsiding basin and of a major rift.

Vertical movements occurred throughout the shield areas from time to time but were of different intensity and magnitude. In consequence, the borders of the shields contain sags which in some places are the marginal edges of basins that now lie mainly beneath the continental shelves. Coastal basins and embayments bordering the basement complex have been the sites of deposition of marine and continental sediments of widely different kinds and amounts at times from the Cambrian on. Volcanic extrusions of different ages have been spread widely in some areas. To a large extint, tectonic movements have controlled the distribution of the continental and marine sediments. During the Paleozoic, in Africa, India, and Australia the shields were elevated, and large areas of continental sediments, varying from lacustrine to aeolian, were deposited. Near the end of the Paleozoic the shield margins were downwarped, and widespread flooding occurred. During the Mesozoic Era a thick sequence of limestone and intercalated sands and muds was deposited. Near the end of the Mesozoic, marked uplift of the continents began, and a long period of erosion followed from Tertiary time to the present. Although many uplifts and downwarps of regions have taken place within the periods in the eras, in general they have been of much smaller regional extent than the movements that marked the end of each era.

The general distribution of the surface rocks and the relationship of mapped faults to them are shown on the accompanying map and text illustrations.

\section{GEOLOGIC FEATURES OF THE MARGINAL OFFSHORE}

The continental shelf is that part of the continental margin covered by the sea. At many places it is a gently sloping plain that on its outer edge steepens abruptly and plunges into the abyssal depths of the sea. At other places the break in slope is more gradual, and the edge of the shelf is not so readily apparent. Generally, however, a marked change is present at about 600 feet $(183 \mathrm{~m})$ in depth, a change which is so prevalent in the world that it has been accepted by oceanographers as marking the approximate outer limit of the continental shelf. The shelves as a part of the continents are, in general, composed of the same kind of rocks as those of the coasts, for they were derived in a large part from sediments eroded 
from the hinterland. Marine limestones may extend into the continental borderland at places where the sea encroached on the coastal margins from time to time owing to a rise in sea level or to a temporary downwarping of the coast. Volcanic flows present within the rocks of the shelves may have had either a continental or a marine origin. Some apparently spread from the coast at a time when the present continental shelves stood above sea level. Thus, the rock sequence of the shelves has been determined by the tectonic forces that have in times past uplifted the continents or lowered the ocean basins. The position of the continental shelves through geological time is ephemeral, however, for ancient continental shelves may have bordered a now submerged land surface or they may have been located within the présent continental land area.

The contour line drawn at 600 feet ( 100 fathoms) on the accompanying map marks the outer border of the present continental shelf. At some places this.shelf is broad, as on the Agulhas Bank of South Africa, which reaches a width of 150 miles; off the Indus valley and western Cutch and the Bengal basin of India; the delta of the Irrawaddy off southern Burma; and the broad Sahul and Rowley shelves of western Aus tralia. Elsewhere the Indian Ocean shelves are narrow, generally not more than a few tens of miles wide.

Continental shelves are bordered on their seaward side by an escarpment that drops into the depths of the sea, at some places abruptly but at most places gradually. This escarpment, termed the continental slope, has according to Shepard (1948, p. 175) an average height of 12,000 feet, although much greater heights are known. The slope may have a relatively smooth surface or may be irregular because of ledges or terraces; it may be interrupted by islands, sea knolls, and other structures, and at some places it is cut by deep canyons.

The submarine contour drawn at 12,000 feet $(2,000$ fathoms) on the accompanying map is considered to be the base of the continental slope. The distance between the 12,000-foot contour and the 600-foot or continental-shelf contour varies markedly as does the gradient over this distance. At many places an intermediate contour, drawn at 6,000 feet $(1,000$ fathoms), is more nearly parallel to the continental shelf than is the 12,000-foot contour. This may indicate a steeper slope to 6,000 feet that at places may represent a fault scarp. The slope beyond this may gradually flatten seaward to the 12,000 -foot contour, possibly in part because of deposition of land-derived sediments that were carried seaward across the shelf to the lower slope.

The manner in which the continental shelves and slopes were formed has been a source of conjecture among geologists (Shepard, 1948). Some have inferred that the shelf was formed by sediments eroded from the coast and deposited offshore. Others consider that downwarp of the continental margins has lowered the sedimentary rocks beneath the sea. Many geologists believe that the outer margins of a larger number of continental shelves are marked by normal faults, often of great throw, or that other normal faults may be present in steplike sequence down the continental slope. This zone of faults is the physical trace of tectonic forces that elevated the continents or downwarped the ocean basins.

Except in a very few places where rock samples have been dredged up, conjecture about the rocks of the continental shelves and the effects of tectonic forces upon them must be based on the projection seaward of the geology of bordering coasts. Accordingly, the continental shelf is described, beginning in South Africa and proceeding generally clockwise from place to place, based on the geologic relationship of the shelf to segments of the coast. (See accompanying Misc. Inv. Map 380 for the location of most place names.)

The Agulhas Bank (fig. 2), off the tip of South Africa, has been described in detail by Wellington (1955). It consists largely of a broad platform of rocks that may be bevelled folds of the Cape System of Paleozoic age, overlain by some Tertiary and Recent sediments. The structure of Agulhas Bank may have been affected to some extent by the tectonic forces that thrust inland from the sea to form the narrow east-west folds of the coastal Cape Mountains. The Cape folding, which involved the entire sequence of the Cape System, 10,000 feet or more in thickness, was most intense to the south, where the beds are highly crumpled, but becomes less pronounced in the borders of the Karroo basin to the north.

The continental shelf is only 2 to 10 miles wide along the coast that extends more than 450 miles in a slightly sinuous line from Port Elizabeth to Durban. This long relatively straight coastline cuts obliquely across the northern part of the Cape "folded" zone and the coastal edge of the Karroo basin to the north. Some South African geologists think this coast marks the site of a flexure; others think that the coastal trend indicates downfaulting. North of $31^{\circ} 31^{\prime} \mathrm{S}$. lat, the Karroo basin is folded down by an east-dipping monoclinal flexure of Early Jurassic age, known as the Natal monocline, which appears to have been caused by the subsidence of the sea floor to the east. Although definite evidence of significant faulting along the trend of the coast is lacking, Wellington (1955) considers that the long, narrow, rectilinear continental shelf suggests faulting. In general, the sediments offshore from Port Elizabeth to Durban are probably of the Cape and Karroo Systems.

About midway between Durban and Cape St. Lucia the continental shelf widens to 28 miles, then narrows again to 4 miles. The wider part of the shelf lies seaward of two west-east-trending coastal faults. If these faults continue offshore, the shelf here may be part of a fault block. North of Cape St. Lucia to Lourenço Marques Bay the coast is nearly straight and at places marked by cliffs. It roughly parallels the Lebombo Mountains, which lie about 50 miles to the west and which are a northward continuation of the Natal monoclinal structure. The shelf, which is here only 3 to 4 miles wide, may mark a fault scarp paralleling the fault along the eastern edge 


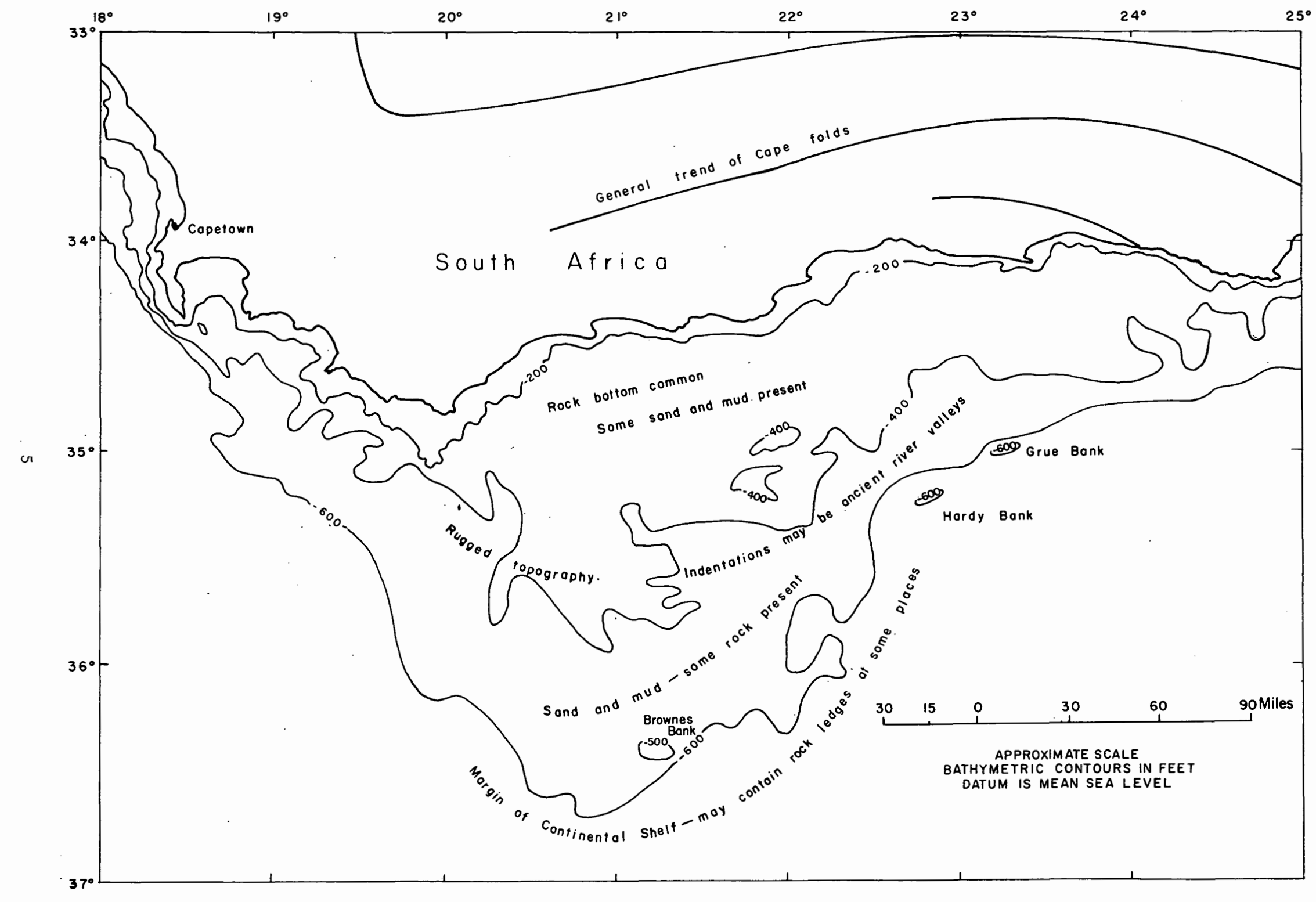

Figure 2.--Diagram of Aguilhas Bank off Cape Colony, South Africa, showing configuration of the continental shelf (based on soundings in U. S. Navy Hydrographic Office chart H. O. 1601.) 
of the Lebombo Mountains. Two structures parallel to the coast terminate near Lourenço Marques Bay-one a synclinal fold lying on the Maputa River, the other an anticlinal fold to the east. The outline of the shoal areas within this shallow bay suggests that the banks may be alined along structures that are similar to and of the same general trend as those on land. (See inset map on fig. 3.) Offshore in the area between Cape St. Lucia and Lourenço Marques Bay, Tertiary and Cretaceous sediments probably overlie Karroo beds.

From Lourenço Marques Bay the coast sweeps northward in a long curve to Beira and is low lying and swampy or sandy throughout. The bordering shelf to Ponta da Barra is very irregular, ranging from 10 to 46 miles in width. The greater widths may be due to structure or possibly in part to accumulation of sediments deposited by the strong current that flows south through the Mozambique Channel and a weaker current that flows northeasterly around Lourenço Marques Bay. Inland 30 to 60 miles from Ponta da Barra is a structural belt which includes anticlines and synclines that curve with the coast. At some places faults parallel these structures, but at others the folds are cut by cross faults that trend northwestward. Similar structures may lie offshore.

The coast from Ponta da Barra trends nearly due north for about 135 miles to $22^{\circ} \mathrm{S}$. This trend is continued farther for 35 miles by two large islands separated from each other and from the mainland by reefs. (See fig. 3.) The shelf narrows from 10 miles at Ponta da Barra to less than 4 miles seaward of the two islands. Two faults and several anticlinal and synclinal structures extend northward along this coast for about 75 miles, and it appears probable that the embayments at Ponta da Barra and south of the two islands were formed in troughs between anticlines.

From the two islands the continental shelf turns northeastward, away from the coastal indentation. Off the coast from the mouths of the rivers near Beira it attains a width of 90 miles. Numerous small shoal areas within this broad shelf are probably coral reefs built on sediments derived from the Rio Save, the rivers at Beira, and the Zambesi. Possibly the broad coastal indentation was originally part of the southern extension of the fault-trough system along and south of the Zambesi valley. Bettencourt Dias (1956) has conjectured that the Save valley, which is south of the Zambesi, is a sunken block of post-Karroo age trending generally east-west but cut by later north-south faults. Possibly, therefore, east-west cross faulting may extend seaward from the coast across the continental shelf and slope, although the trend of the coastline may be affected by faults of a general north-south trend.

The shelf which is 40 miles wide near the Zambesi delta, narrows to a width of 11 miles at $17^{\circ} 10^{\prime} \mathrm{S}$. lat, $39^{\circ} \mathrm{E}$. long, more than 200 miles to the north. Du Toit (1937, p. 254) shows on his map of the rift system an "associated fracture" lying seaward of this coast at about the outer edge of the continental shelf. Probably "fractures" or normal faults are present in the basement on the coast and offshore on the continental slope also.

The geology of that part of the continental shelf of Mozambique so far described is closely related to the geology of the coast and its hinterland. Figure 3 shows structure on top of the Jurassic(?) basalts in southern Mozambique, based on the estimated datum of these basalts below sea level in three wells (Nos. 3, 4, and 5) drilled in search for oil and gas. The contours, which were extrapolated westward to the Lebombo Mountains and eastward to the coast, indicate a monocline that is broadly arcuate north and south. The westernmost contour was drawn at a depth of $-2,000$ feet, based on an estimated thickness of the Cretaceous, which probably terminates in the subsurface along the fault scarp that Bettencourt Dias (1956) notes as probably having formed along the eastern border of the Lebombo Mountains in late Karroo time. The contours swing northeastward, and at the north follow the trend of the east-west scarp of the Archean platform toward the coast. Although African geologists have not shown faults to lie along this scarp, such faults may be present, assuming that early Niesozoic rocks are in contact with the Archean basement beneath the Quaternary cover.

Although figure 3 outlines roughly the possible shape and depth of the monocline to the top of the Jurassic(?) basalts, the effects of block faults are not shown because their relationship to the monocline is not known. Lacking information from geophysical mapping or other exploratory work as to the amount of sediments, Karroo or other, that lie below the basalt datum, the writers can only speculate about the total thickness of sediments or the depth of the basement complex. However, 6,000 to 10,000 feet of Karroo is estimated to be present across the channel in Madagascar (Hourcq, 1953), and it would not be unreasonable to expect at least 7,000 feet of Karroo below the Jurassic(?) basalts within the $-13,000$-foot contour along the coast of Mozambique. Thus, in the vicinity of Cape Sao Sebastiao the basement complex may lie at a depth of about $-20,000$ feet, or possibly even deeper if the normal faulting along the coast was intense.

From the nature of the rifting in northeastern Africa and its probable continuation south of the Zambesi River, as noted by Dixey (1956, p. 47), it might be assumed that several faults, both along the coastline and offshore, may be present south of Beira. These may have developed at an early geologic period or may have appeared consecutively from Karroo time onward as the Mozambique geosyncline was downwarped.

The continental shelf of Mozambique north of the area shown in figure 3 is relatively narrow. From Mozambique port to the boundary near the Ruvuma River the shelf is only 2 to 15 miles wide. North of Bay de. Pemba many islands and coral reefs are present offshore, and the shelf is irregular as well (Continued on p. 8.) 


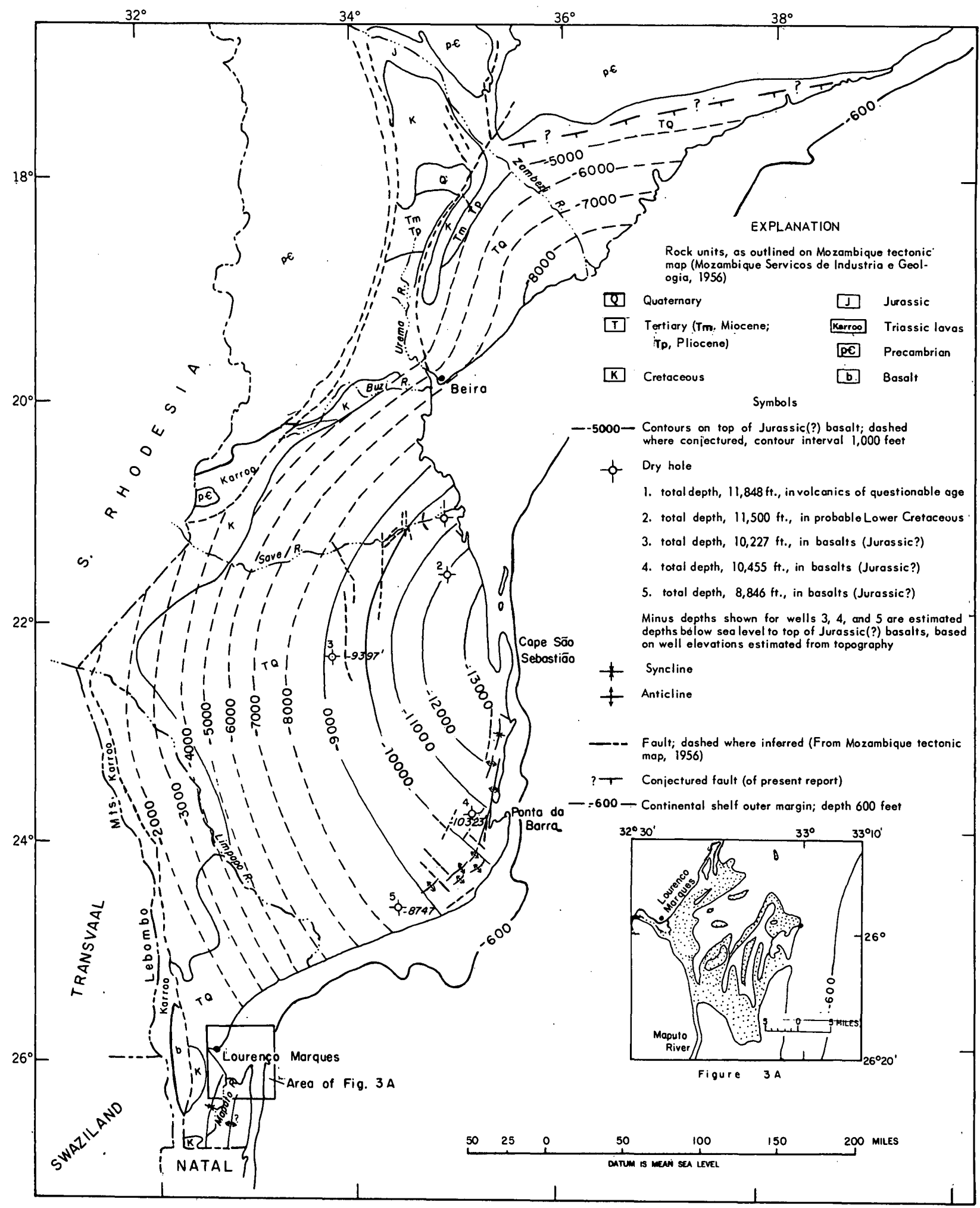

Figure 3.--Map of southern part of Mozambique showing surface geology and structure and conjectured subsurface contours on top of Jurassic(?) basalt based on well data, which indicate monoclinal structure coastward from the Lebombo Mountains. 
as narrow. Wellington (1955, p. 188) indicates that the character of the coast between Mogincual, at about $15^{\circ} 30^{\prime} \mathrm{S}$. lat, and Cape Delgado, just south of the Ruvuma River, suggests very strongly a faulted origin during Cretaceous time.

The continental shelf of Madagascar is generally narrow, averaging 15 miles in width, but attains a width of 100 miles on the northwest coast of Cape St. Andre and 50 miles off the southern coast. At some places, as along the northeast coast, no shelf is present. The remarkably straight east coast is bordered by a narrow shelf whose edge is a fault scarp, shown on the tectonic map (Besairie, 1954) to extend from Fort Dauphin to Be.d'Antongil. The scarp dips steeply to 6,000 feet, and the continental slope to this depth lies along the fault plane. Be d'Antongil, which is bordered on each side by a fault trending northwestward along its shore, is probably a down-faulted block trending at an acute angle to the main coastal fault. East of $\mathrm{Be}$ d'Antongil a fault about 80 miles long parallels the coast but is offset eastward from the main fault that borders the island on the east.

In southwest Madagascar, faults in older rocks that lie inland from the coastal Tertiary sediments are presumed to have their counterpart off the continental shelf.

On the west, the shelf from Morondava to Cape St. Andre contains many small banks and coral reefs. Some on the outer edge may rest on volcanic cones.
The island of Juan de Nova, which lies close to the shelf at the broadest part, is reported to contain granite; thus part of the broad shelf may contain granites similar to those exposed on Cape St. Andre.

The shelf from Cape St. Andre toward Cap d'Ambre averages about, 30 miles in width but broadens west of Cap d'Ambre to include a number of reefs, some. of which may cap volcanic cones, possibly of postCretaceous age like the volcanic flows on Cap d'Ambre. The arcuate coast northeast of Cape St. Andre parallels the belts of rocks of the interior, which range from late Karroo rocks bordering the basement complex to Eocene and younger Tertiary rocks that fringe the coast and form the Majunga basin. The arcuate arrangement of these belts of rocks suggests that they form the southern rim of a large ancient basin that may now lie seaward of the continental shelf and continental slope to water depths of more than 6,000 feet and may reach as far north as the volcanic chain of the Comores Islands.

The present writers, following the concept that faulting has been recurrent throughout geologic time in the Mozambique-Madagascar region, have drawn a diagrammatic cross section (fig. 4) along the $22 \mathrm{~d}$ parallel from coastal Madagascar to Mozambique, based on their extrapolation of the few data available from seismograph mapping and well drilling. The sedimentary sequence and position of faulting shown in the diagram are conjectural, particularly in the channel. The estimated depth to basement of about

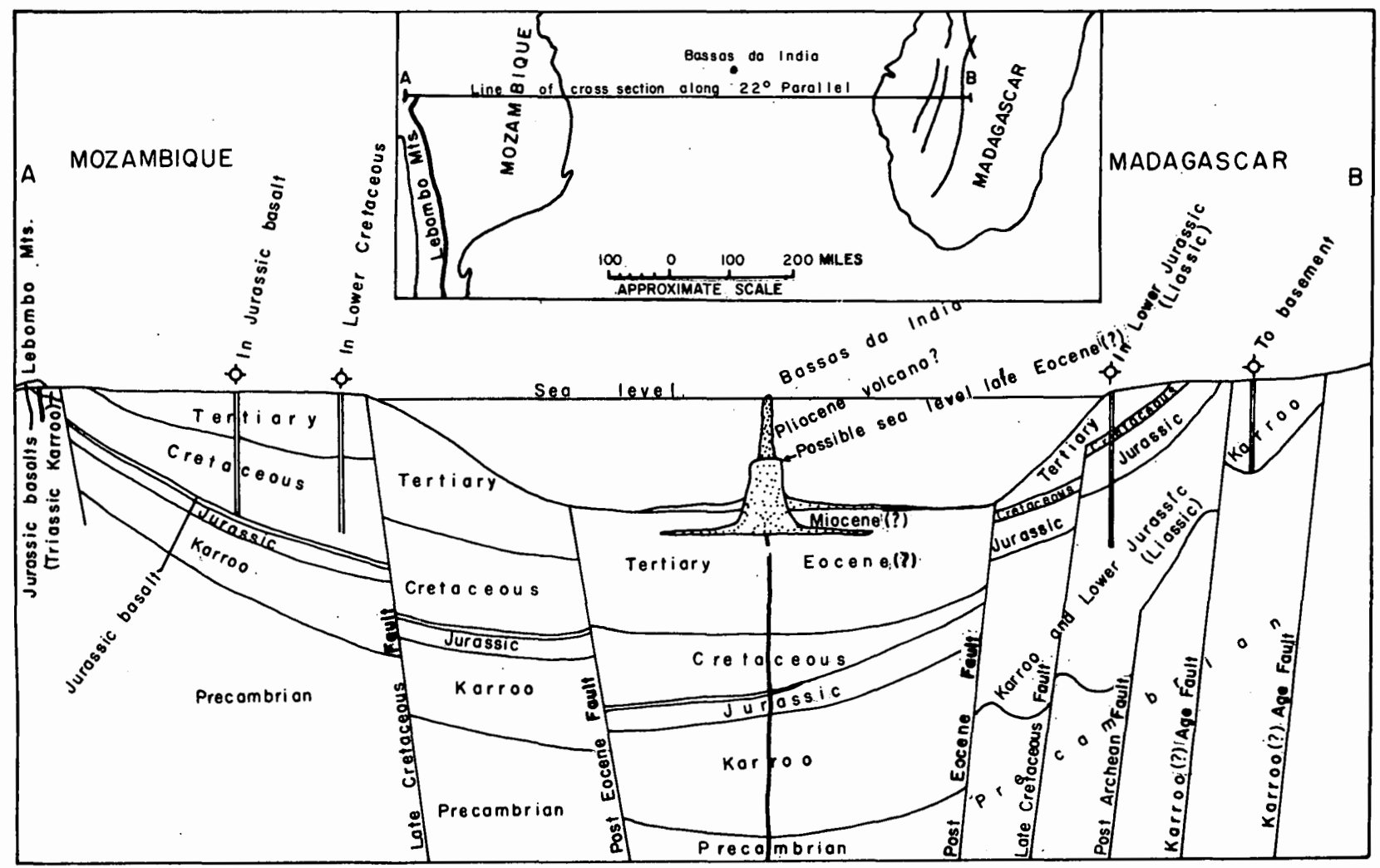

Figure 4.--Diagrammatic cross section showing hypothetical structural relationship of the rocks along the 22d. Parallel between Mozambique and Madagascar. (Vertical exaggeration approximately $40 \mathrm{X}$ ) 
25,000 feet in the Mozambique Channel as shown on the cross section is conservative, for Dixey (1959, p. 361) states: "The geosyncline***is one of the world's deepest, since the Karroo sediments indicate a subsidence of about 5 miles, and the post-Karroo sediments an additional 4 miles (Falcon, in discussion, Dixey, 1956)." Thus, the basement as indicated by Dixey must lie at a depth greater than 47,000 feet. The geosyncline shows, according to him, that ${ }^{1 * * *}$ at different ages extensive faulting has occurred along its shores, and in the early Jurassic and in the Cretaceous these movements were accompanied by intense vulcanicity."

The faulting in Madagascar shown in the cross section is assumed to have begun in post-Archean time and continued into the Karroo. The continental shelf was probably faulted during the Cretaceous, and the fault shown at the foot of the continental slope is postEocene. The older faults were undoubtedly rejuvenated during subsequent normal faulting. Differential vertical movements between fault blocks, however, may not have been of the same order of magnitude, and the movement of any one block has not always necessarily been in the same direction in each new period of faulting. A well drilled in coastal Madagascar, which has been projected to the line of the cross section, stopped in Jurassic sediments at about 13,000 feet. Seismograph mapping nearby indicates that the basement lies at a depth of 25,000 feet. On the basis of these data, the block lying west of the continental shelf is assumed to have moved downward during Late Cretaceous time, and accordingly the basement rises from a depth of 25,000 feet in the vicinity of the well on the coast westward to the eastern edge of the downdropped block, where it forms a ridge on the slope. The faults that are shown at the foot of the continental slopes of Madagascar and Mozambique mark the borders of a block that is presumed to have sunk during post-Eocene time (probably late Miocene). Upon this sunken block are the volcanic islands of Bassas da India and Ile Europe, which rise from an elongate platform of probable volcanic origin that apparently lay near sea level during the Miocene. The volcanic is lands thus would have been formed in Pliocene or pleistocene time. No paleontological information is available on the age of the coral reefs surrounding these islands, and their fauna may be older than Recent.

Small patches of igneous rock along the southwest coast of Madagascar and the presence of granite on the island of Juan de Nova off northern Madagascar indicate that ridge and trough structures may lie close to the western coast of Madagascar. Figure 5 is a diagrammatic cross section showing hypothetical relationships of rocks underlying the Mozambique Channel along a line between Madagascar and Mozambique north of the island of Juan de Nova.

Geophysical measurements in the Mozambique Channel have been interpreted by Talwani and Worzel (1960) as indicating that the rock structure beneath the channel is not continental. Talwani (1962, p. 1177), however, states that "The crust under the Mozambique Channel cannot be a typical oceanic crust***" The floor of the Mozambique Channel along the line of section of figure 4 lies at depths of not more than 11,000 feet, according to chart soundings. It does not seem reasonable, therefore, that the floor of the channel, which here lies at an elevation higher than the base of the sedimentary troughs, should be composed largely of simatic rocks of a noncontinental type. The present writers recognize that blockfaulted structures may be more prevalent in the Mozambique Channel than the two diagrammatic cross sections (figs. 4 and 5) indicate. These structures could cause a variation in the geophysical measurements. Also, thick flows of lava of Tertiary to Pleistocene age may be present, which could affect geophysical measurements.

On the mainland, the Tanganyika coast for more than 130 miles, from Ruvuma Bay at the mouth of Ruvuma River to about $8^{\circ} 42^{\prime}$ S., contains many cliffs and is fringed throughout by reefs. The continental shelf probably averages no more than 3 miles in width and follows closely the deep indentations in the coastline. The narrowness of the shelf strongly indicates a downfaulted margin and suggests the possible presence of Jurassic, Cretaceous, and Tertiary sediments on the slope equivalent to those on the coast.

On the geologic map of Africa (Commission de la Carte Geologique Internationale de l'Afrique, 1952) at approximately $8^{\circ} 42^{\prime}$ S., a fault extends eastward from the basement complex to the coast. The outline of the Jurassic outcrop on either side of this fault suggests that the area south of the fault is a downdropped block. (See fig. 6.) From the vicinity of the fault, which may extend onto the continental shelf, the shelf broadens greatly, trending northeastward around the island of Mafia, which it borders closely. The shelf turns northwestward from the north end of Mafia and narrows from 45 miles to about 4 miles near the mainland. Many patches of coral reefs are present on this shelf. West of Mafia, a large river, variously designated the Rufyi, Rufiyi, and Lufyi, has spread deltaic sediments along the coast and has probably extended the continental shelf seaward to its present position. Faults of the same general northeastsouthwest trend as those in the Archean nearby on the mainland may be present along the continental shelf east of Mafia, and between Mafia and the mainland coast under the cover of deltaic sediments.

From the headland at $7^{\circ} \mathrm{S}$. the shelf is narrow as far north as Dar es Salaam, where it widens northeast ward and passes closely along the east coast of the is land of Zanzibar, then turns northwestward and approaches to within a few miles of the mainland opposite Pemba island. (See fig. 7.) The shallow channel between Zanzibar and the mainland probably contains a relatively thick sequence of Recent sediments, deposited in part by the Ruvu River. West of a narrow belt of Tertiary and Quaternary sediments on the mainland opposite Zanzibar, Cretaceous marine rocks rest upon Jurassic rocks that lie in a downfaulted block in contact with the Precambrian complex. The faulting here trends northeastward, but at about $4^{\circ} 40^{\prime} \mathrm{S}$. it turns northwestward and becomes part of a series of parallel faults that probably mark a rift. Faulting of Late Cretaceous age and of the same general trend as that back from the coast may be present in the channel between Zanzibar and the coast, and a thick sequence of Tertiary may be present there under Recent sediments. (Continued on p. 13.) 


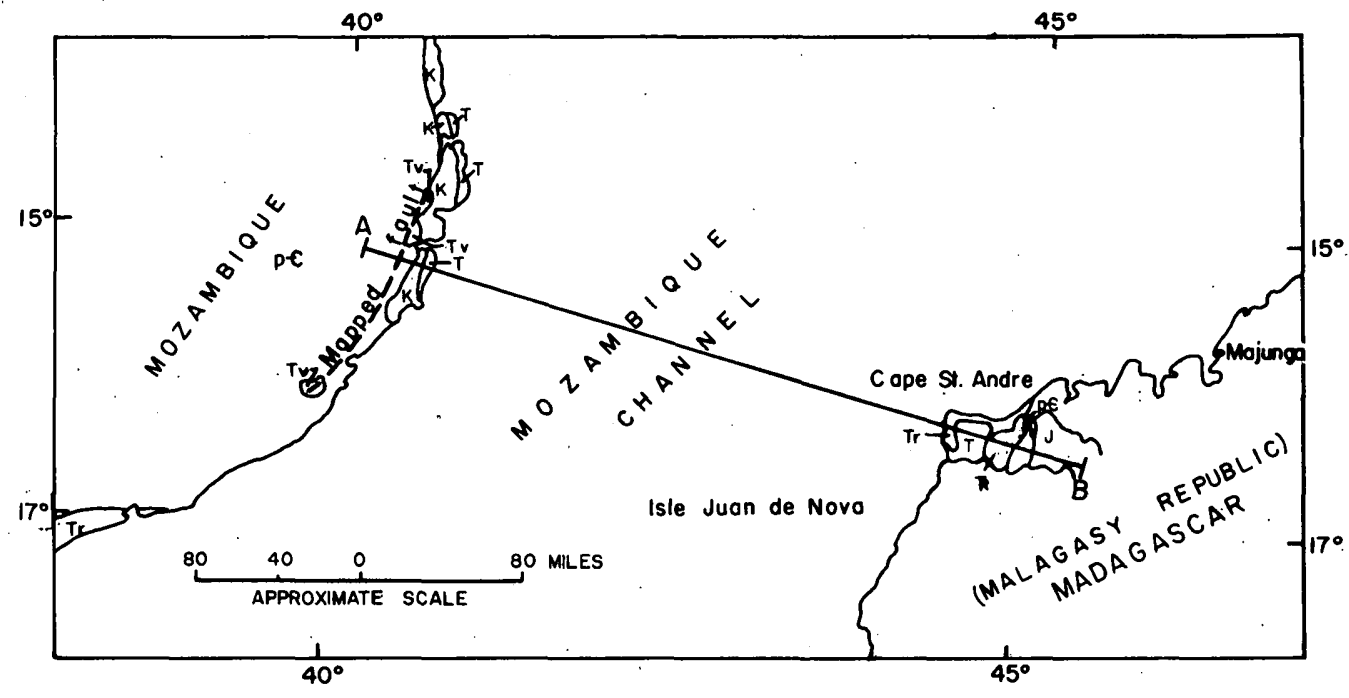

Index map for Figure 5

A

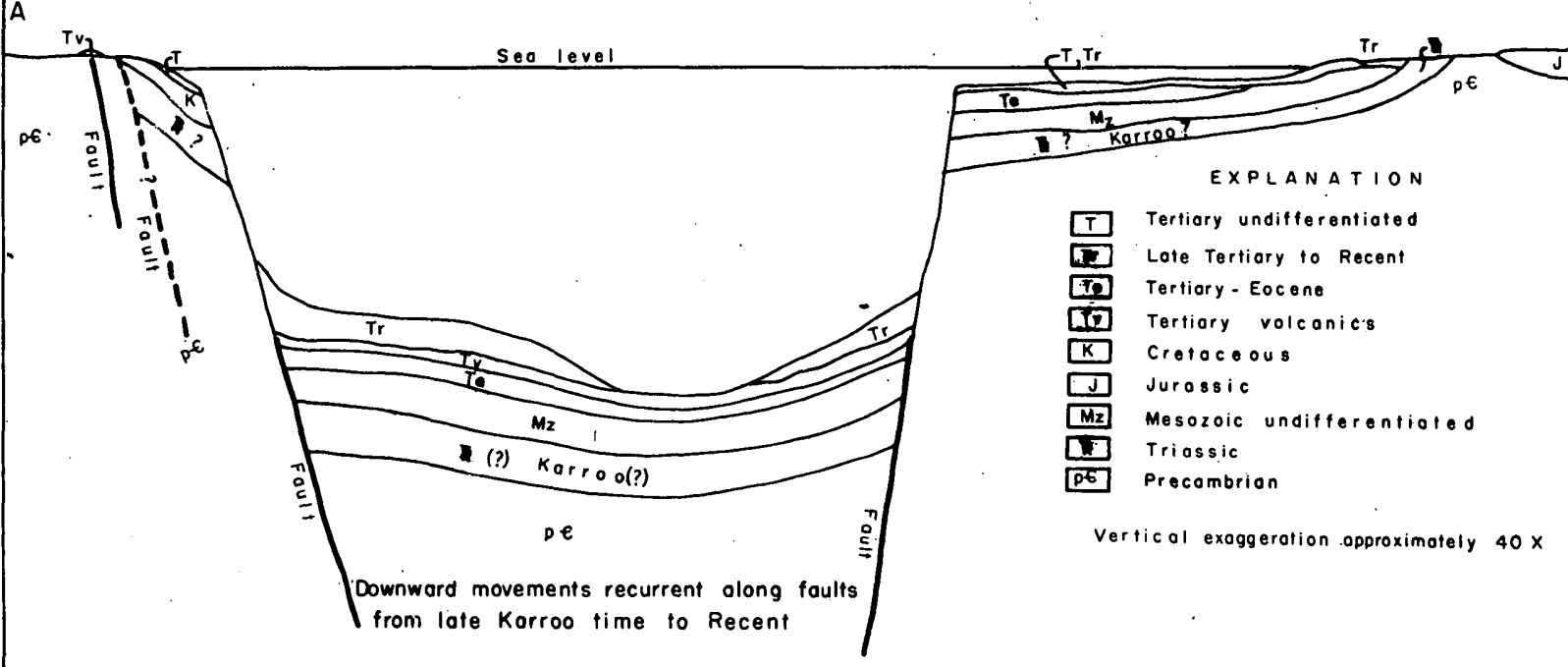

Figure 5.--Diagrammatic cross section showing hypothetical relationships of rocks underlying the Mozambique Channel along a line between Mozambique and Madagascar north of the island Juan de Nova. 


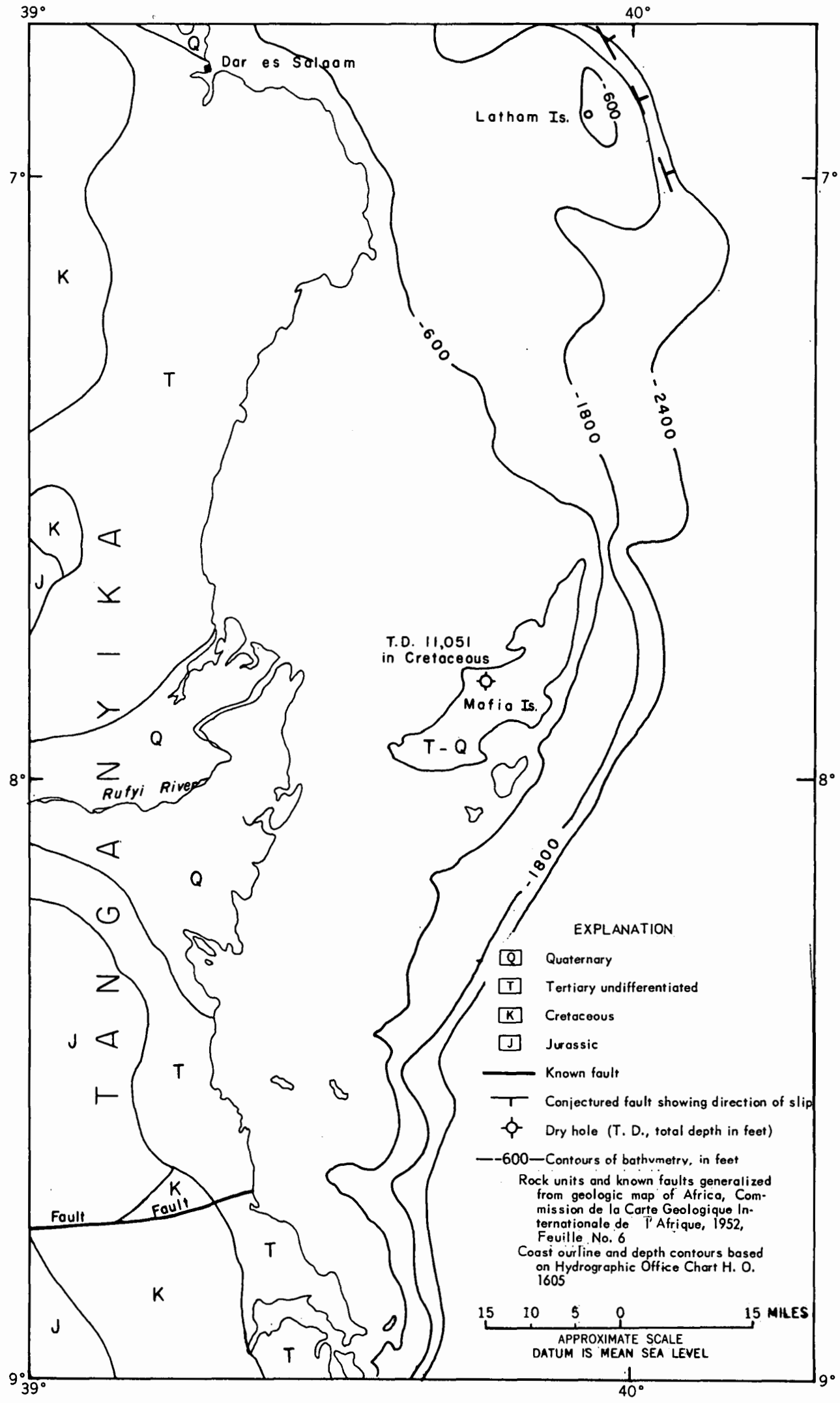

Figưre 6.--Diagram showing configuration of continental shelf and the geology of Mafia Island and of the bordering Tanganyika coast. 


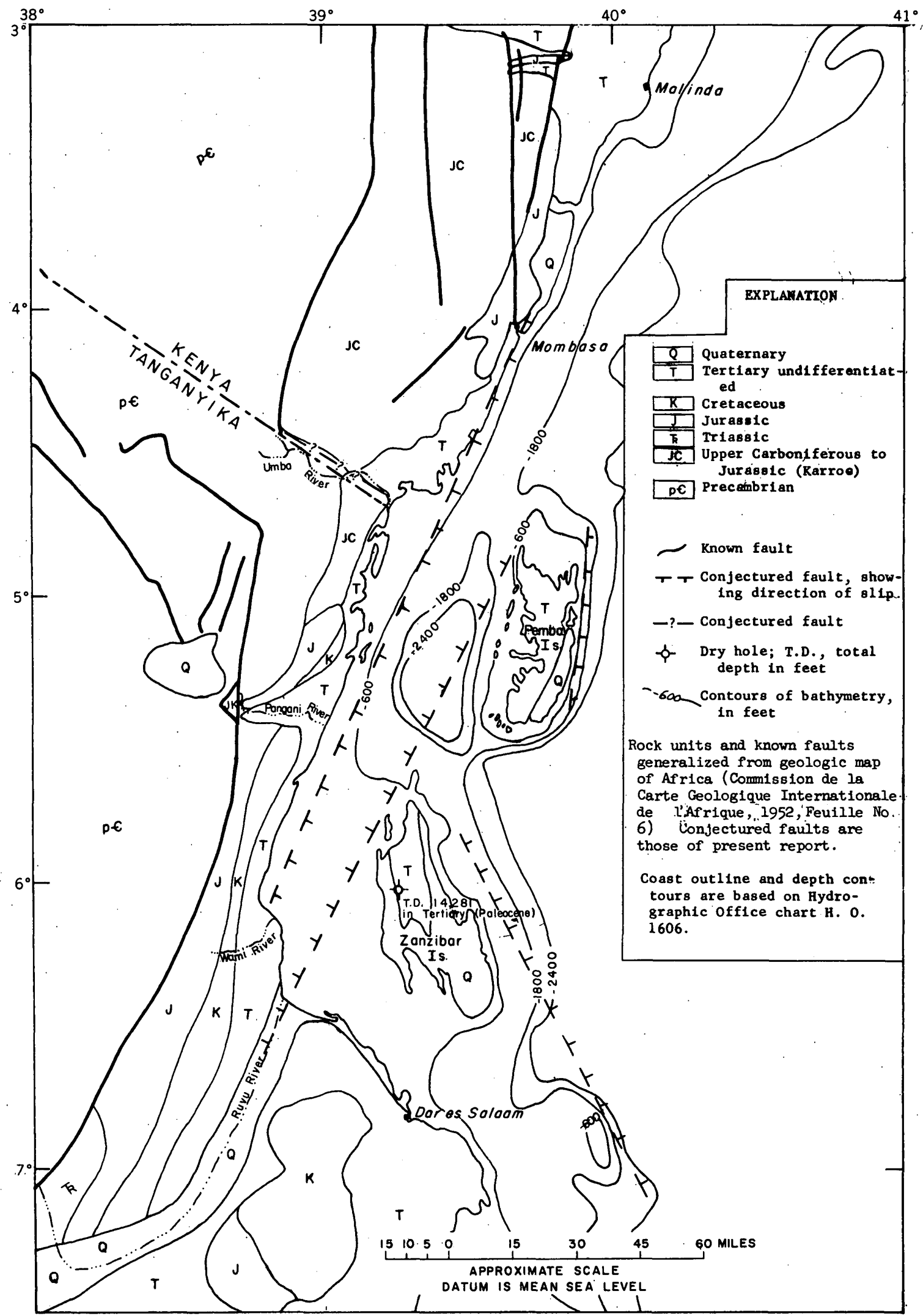

Figure 7.--Diagram showing possible structural relationship of rift faults in Tanganyika and conjectured faults offshore bordering Pemba and Zanzibar 
The coastline of Pemba is notched by many small indentations that are bordered on their seaward edge by fringing reefs. (See fig. 7.) The continental shelf is extremely narrow around the island except off the north end and some places on the west. Between Pemba and the mainland the slope drops to a depth of about 1,800 feet the full length of the island and then to 2,400 feet, except at the north. Westward for about 16 miles the bottom is relatively flat, then rises gradually to the margin of the mainland shelf, which is here about 6 miles wide.

Some geologists have conjectured that the deep sea basin west of Pemba is a downdropped block lying between offshore faults that parallel the coast of Pemba and the mainland. The present writers suggest that these faults may project southward under the deltaic sediments of the Zanzibar channel. The eastern fault, if extended southward from Pemba, would pass close to the northwest coast of Zanzibar and nearly down the northward course of the Ruvu River, which from its headwaters flows southward and then abruptly changes trend to northeastward and flows into the Zanzibar channel. The westernmost fault may parallel the coast southward to about $6^{\circ} \mathrm{S}$. and terminate at the mainland as indicated in figure 7.

Soundings are not spaced closely enough between Zanzibar and Pemba to show whether there is a connection between the 2,400-foot depth contour of the trough and the same depth to the southeast in the Indian Ocean. Therefore, the Pemba channel trough may be separated from the Indian Ocean to the southeast by a narrow sill. The north end of the trough is separated from the Indian Ocean by a wide sill shallower than 1,800 feet.

Figure 7 shows faults that have been mapped along the African coast in this general area and additional faults conjectured in this report to be present from the pattern of exposed formations. North of the Pangani River, toward the Tanganyika-Kenya border, a narrow belt of Karroo sediments lies in contact with the basement complex. At the Kenya line, however, the Karroo sediments broaden greatly and are in fault contact with the basement complex. The indentation in the coast at the Tanganyika-Kenya line and the widening of the Karroo sediments to the west along this line suggest strongly that a southeastward-trending fault may be present. Faults mark the contact between a narrow belt of Jurassic rocks and Karroo sediments close to the coast north of Mombasa and between a similar belt of Jurassic rocks and the basement complex south of the Pangani River. Thus, it does not seem impossible that the area between Mombasa and Dar es Salaam, including the islands of Pemba and Zanzibar, may contain several downfaulted blocks, and that Pemba and Zanzibar and possibly Mafia remain as part of an older mainland surface. The straight shelf line east of Pemba may indicate a fault scarp. A fault conjectured to be present in the continental slope northeast of Zanzibar may continue southeastward along the slope east of Latham Island.
From northeast coastal Kenya northeastward along Somali Republic to Cape Guardafui the coast is mostly rocky with few indentations and is rimmed by a narrow beach. Cape Guardafui, which forms the tip of of the Horn of Africa, faces north and east and shows on its north face a nearly vertical wall of rock that rises from the deeps to a height of 900 feet above the sea. The continental shelf along this coast northeastward from Kenya is narrow, averaging about 12 miles but reaching 30 miles in width at places.

Northward from Mombasa a large triangular area covered by Quaternary sediments is apparently a broad, deep basin, probably a fault trough. The fault shown in figure 7 west of Mombasa along the contact of the Precambrian and younger rocks probably extends northward along the Precambrian rocks that mark the western margin of this basin. Along the northern margin, the Quaternary sediments are in contact with Jurassic sediments and the Precambrian basement. Jurassic and Cretaceous sediments may be present within the basin beneath the Quaternary cover. The thickness of sediments is not known with certainty, but geophysical data indicate that the sediments in coastal Kenya reach a thickness of 20,000 feet. (Pulfrey, 1956). The narrow shelf along the coastal part of this basin probably contains an equal thickness or more because of normal faulting.

A well (no. 14, fig. 8) drilled near the basement complex in a narrow coastal belt of sediments north of this basin reached a depth of more than 11,000 feet. The sedimentary sequence present in this well may have been deposited upon a steep basement slope, but the prevalence of normal faulting mapped in rocks bordering the East African coast suggests that a normal fault separates the sediments and the basement complex under the Quaternary cover.

Between Mogadiscio and Cape Guardafui a large triangular-shaped basinlike area covered by Tertiary and Quaternary sediments reaches from the coast westward across the Somali Republic into the Northeastern part of Ethiopia. Mapping in Ethiopia and former British Somaliland (northwestern Somali Republic) by geologists for oil companies has determined the stratigraphic relationships of Mesozoic rocks around the rim of this basin (Taylor, 1948a, b, c; and Clift, 1956). From the conjectured contours in figure 8 it appears that Mesozoic and Tertiary rocks probably form an eastward-thickening sequence throughout the basin. The geologic history of the Somali Republic is closely tied to that of eastern Ethiopia. Incursions of the sea during Mesozoic and early Tertiary times deposited marine limestones and evaporites throughout the basin area; intermittent uplift of Ethiopia since early Tertiary resulted in erosion and spreading of sediments widely across this basin in Somali.

The basin appears to lie between two large faults. This is suggested by (1) faulting shown on the geologic map of Africa (Commission de la Carte Géo(Continued on p. 15.) 


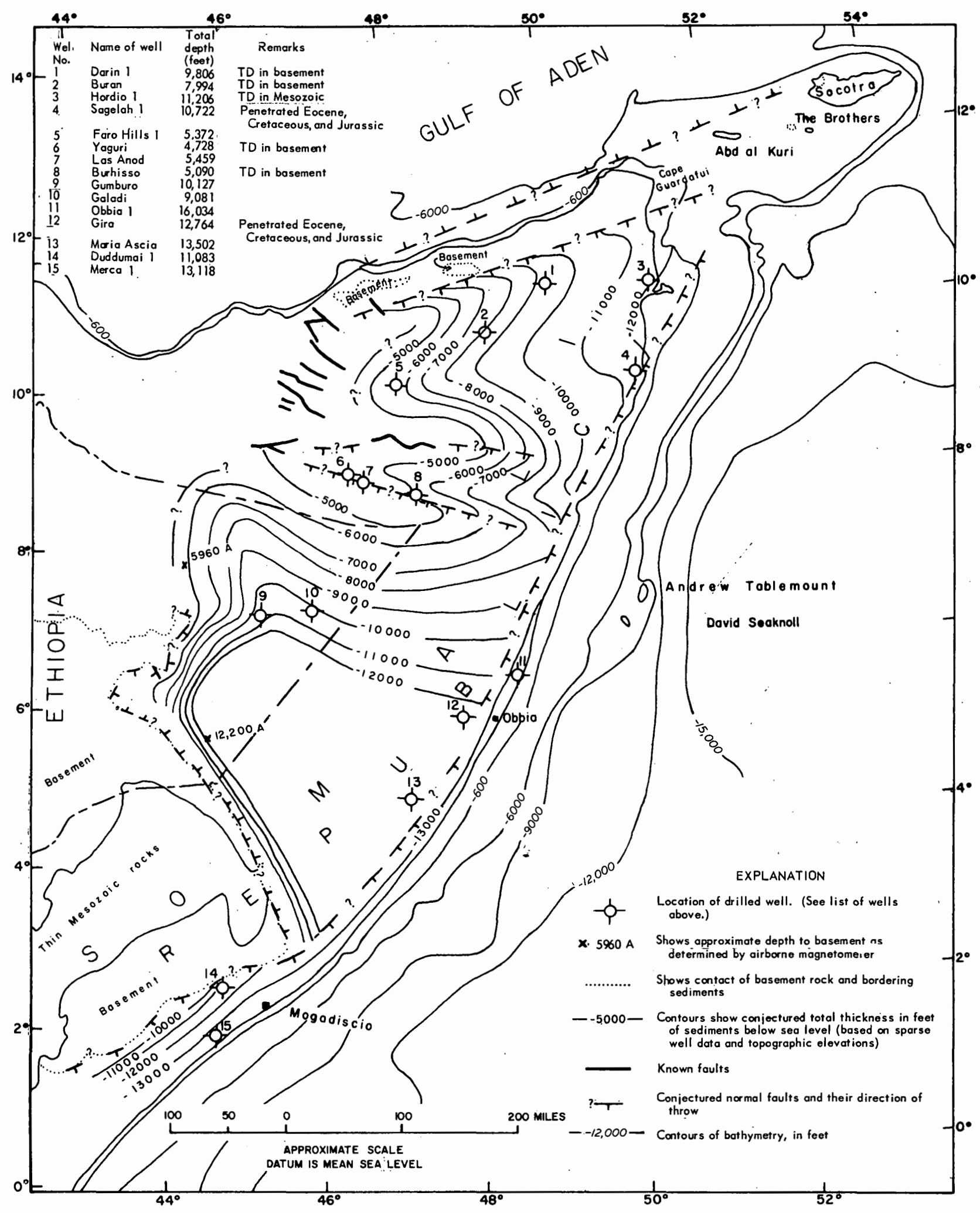

Figure 8.--Diagram showing conjectured normal faults within the Somali basin and thickness contours of sediments that may be present on the basement floor between the faults. 
logique Internationale de l'Afrique, 1952; (2) faulting conjectured by the present writers from data on wells in Somali that reached basement or depths in excess of $12,000 \mathrm{feet}$; and (3) depths to the basement as determined from an airborne magnetometer profile northward across the western tip of the basin (Agocs, Isaacs, and Hartman, 1958). One of the two large faults is inferred to be present along the north side of the Archean complex that bounds the basin on the south; the fault appears to dip steeply. The other fault is presumed to lie in northern Somali on the south side of Archean outliers and bordering post-Archean rocks that form 1 a series of horstlike blocks of northeast trend. The faulting shown on the geologic map of Africa trends generally northwestward in former British Somaliland. This and the similar trend of the fault along the apparent downthrown block of some 13,000-foot throw which borders the Archean to the south suggest that the basin deepens from north to south by a series of parallel steplike faults that gradually lower the sediments into the deepest part. Although the fault ing thus indicated trends northwestward, a fault must also closely parallel the coast in a northeastward direction, because a well (no. 11 on fig. 8) drilled to a depth of 16,034 feet near Obbia contained a greater thickness of sediments than could be expected from the projection coastward of depths of wells drilled nearby and within the basin. This well may have been drilled within a northwestwardtrending fault trough, but the thickness of the sediments penetrated suggests that the well lies on the east side of a downthrown block. A fault has been postulated offshore parallel to this coast.(Du Toit, 1937, fig. 3), and perhaps other faults are present on the continental slope.

The well is particularly interesting in that it apparently penetrated sediments to a depth of more than 15,000 feet below sea level, which is nearly as deep as the deepest part of the sea basin off Somali Republic to the east. Thus it would seem unlikely that this offshore basin would contain dense simatic rocks near its surface. If such rocks are present, however, then a fault trough containing a great thickness of sediments must lie between the offshore deep and the coast.

Northeast of Obbia, two sea features, the David Seaknoll and the Andrew Tablemount, lie about 40 miles east of the coast and parallel to it. (See fig. 8.) If later exploration should reveal similar features to the north or south of these features and approximately in line with them, the trend would indicate a rise of lavas along a fracture. Such a fracture system parallel to the coast, however, would be approximately at right angles to a ridge on the sea floor that Farquharson (1935-36, chart) has shown trending directly into the continental slope and shelf at Obbia.

The faults conjectured by the writers to be on the south side of the Archean outliers that trend across northern Somali may extend as far east as the south side of Socotra, for the narrow continental shelf east of the rocky coast of the-Horn of Africa appears to be faulted in a series of blocks that are separated by troughs deeper than 600 feet. These blocks are sur- mounted by the islands of Abd al Kuri, The Brothers, and Socotra. Precambrian rocks exposed in Socotra are surrounded by post-Archean rocks like the horstlike blocks of northern Somali Republic. Precambrian rocks are also exposed in the westernmost of The Brothers Islands.

Some of the tectonic features of the northeastern part of Africa may continue for a considerable distance on the floor of the northern Indian Ocean and the Arabian Sea. From a detailed study of data resulting from the John Murray Expedition in 1933-34, which mapped some 22,000 miles of this part of the ocean floor, Wiseman and Sewell (1937) have drawn a number of features, some of which they consider to be related to structures of the bordering lands. One of the larger features, the Carlsberg Ridge, was traced from the vicinity of Socotra Island southeastward to the vicinity of the Chagos archipelago, thence through a bend, first south and then west of south. Wiseman and Sewell consider these ridges and other related structures in the northwest Indian Ocean a mirror image of the trends of the Rift Valley in Africa. The validity of this concept must await further and more intensive exploration of the possible structures in the northwest Indian Ocean.

Along the northern Horn of Africa the coast drops steeply by a series of steplike fault blocks into the Gulf of Aden at most places, and the shelves are narrow or nonexistent. The deep trench or great $r$ ift that lies in the Gulf is bounded on either side by zones of faulting. According to Girdler (1958) the Gulf of Aden was downfaulted probably in late Pliocene time. The Gulf has an east-northeasterly trend, and cuts right across the Arabo-Somali part of the ancient shield. Henson ( in discussion, Quennell, 1958) regards the Gulf of Aden as a faulted synclinal trough rather than a rift valley, with a floor doubtless smoothed by sediment but crossed by prominent northeast-southwest ridges which are too large to be dikes and which follow one of the pronounced trends of the region. According to Swartz and Arden (1960), movement of four blocks caused tensional effects that formed the Gulf of Aden and the rift valleys of Ethiopia; the "Horn of Africa" began to separate from the Arabian peninsula during the early Miocene, and the Gulf of Aden was formed during the Pliocene.

The shelf off southern Arabia is generally narrow, büt at a few places to the west off Aden and to the east off Muscat and Oman it is as wide as 50 miles. The coast and continental shelf throughout this area have been strongly affected by faulting, for they lie on the northern rim of the Gulf of Aden. Although faults within the rocks of the coast and probably in those of the shelf are essentially parallel to the coast, numerous irregularities in the coastline are probably due in part to transverse faults that form the northeasttrending troughs in the Gulf of Aden, which lie at acute angles to the Arabian shore. If the east-west faults on the south coast of Arabia that are shown on the tectonic map of Africa (Association des Services Géologiques Africains, 1958) continue offshore, they probably cut the northeast-trending troughs in numerous angular fault blocks. The shelf off southern Arabia may have been subjected to faulting as early as the 
Jurassic and may have been downfaulted again during the Miocene. Another concept, however, is that the western Arabian coast and Socotra may have been downfaulted as late as the Pleistocene.

At the eastern end of the Arabian peninsula a narrow continental shelf borders the coast from the island of Masirah to Ra's al-Hadd. (See fig. 9.) Some geologists believe that the northeast-southwest trend of the coast formed by large-scale normal faulting that occurred in Miocene or post-Miocene time. This faulting marks the southern boundary of the Oman orogenic belt, whose present trend and connections beneath the sea are uncertain. An extension southwestward of a fault off this coast would be in line with probable faulting off the east coast of the Republic of Somali.

Rocks bordering the coast of southwest Arabia include ancient granites and later metamorphic and volcanic rocks. Farther east a sequence of sedimentary beds of Cretaceous to Tertiary age may attain a thickness of 30,000 feet toward the island of Masirah (Agocs, Isaacs, and Hartman, 1958). The island of Masirah, which is separated from the coastal sediments by a fault, consists largely of serpentines bor dered by a thin belt of Tertiary rocks.
The Gulf of Oman lies in a southeastward-trending trough that may have been downwarped in Miocene time. The trough is probably bounded by faults but may be a faulted syncline rather than a "rift" block, and the margins of the syncline may lie along the narrow continental shelf, which is probably also faulted. (See fig. 9.)

At many places the Mekran coast consists of cliffs as high as 800 feet, whereas contiguous coastal areas are indented by embayments whose shores are low and swampy. The cliffs are sea-cut ranges of hills, which parallel east-west inland folds. To the west these folds swing northwestward to join the Zagros Mountains of western Iran; to the east they join north-trending folds west of Karachi. The continental shelf, which averages about 12 miles in width, is broadest where reentrants are deepest but tends to narrow off the steep coast. Many geologists believe that the continental shelf and slope off the Mekran coast have, been downfaulted but disagree as to the age of the faulting, which is considered by some to be Miocene and by others to be as late as Pleistocene. The continental slope and sea floor are thought to contain ridges par allel to the mountain chains of the coast. If sediments offshore are similar to the Tertiary sediments of the coast, they probably are thick.

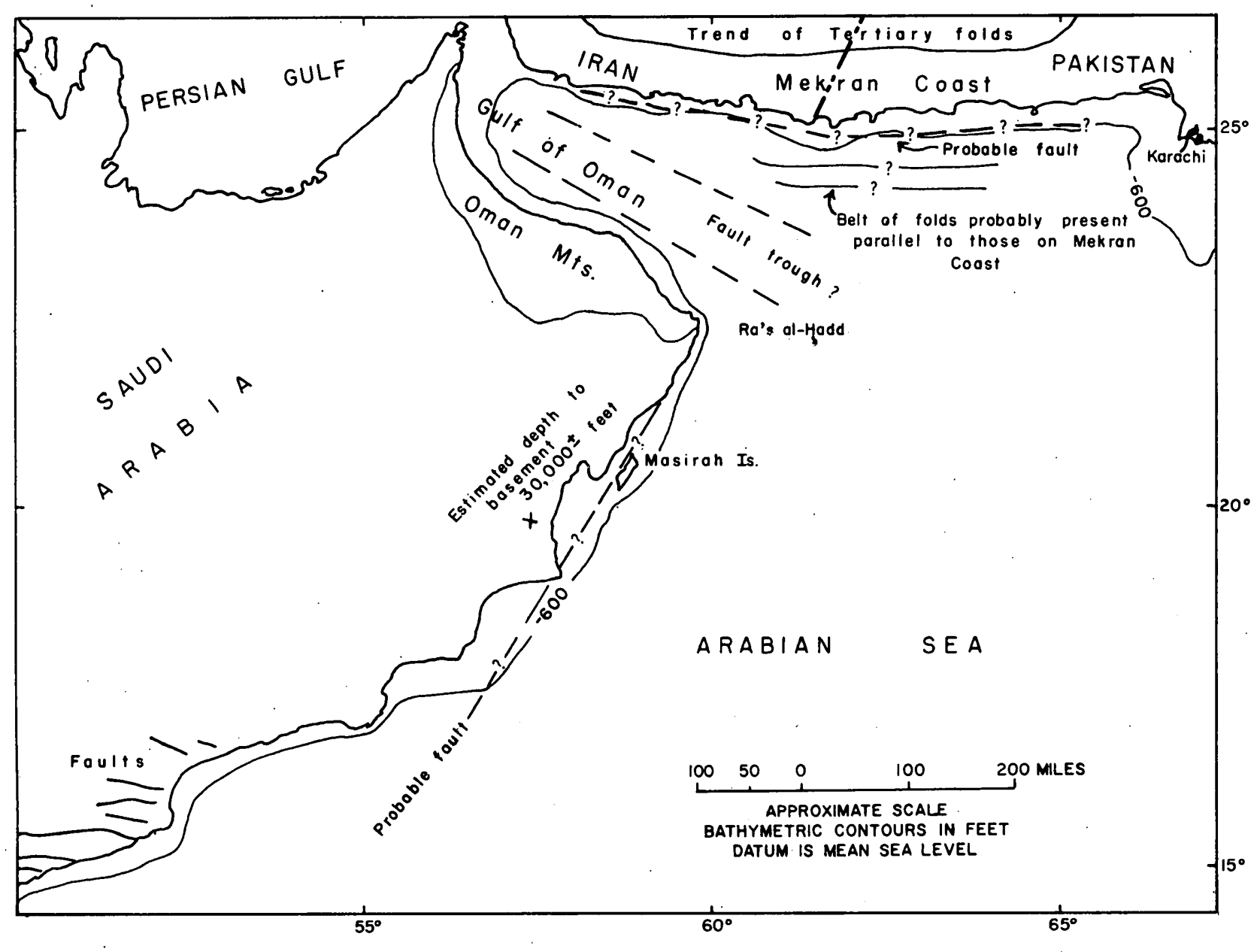

Figure 9.--Outline map of a part of the Arabian and Mekran coast, showing some structural features of the coast and conjectured features offshore. 
The shelf broadens markedly southwest of Cape Monze near Karachi from about 60 miles to a width of 100 miles southwest of the north coast of the Gulf of Cutch. Its great width over a distance of about 215 miles is due to sediments spread along the coast from rivers on the Indus delta. A reentrant about 60 miles long, known as the Swatch, indents the otherwise remarkably even shelf, but depths within the Swatch are mostly shallower than 1,500 feet. Tertiary beds in the Cutch area have been estimated to be about 2,500 feet thick. Ghosh (1959) notes that the Rann of Cutch and the continental shelf to the west, which is shallow, may contain folded Tertiary beds below the sea floor.

The trend of the coast and shelf south of the Gulf of Cutch toward the Gulf of Cambay is shown in figure 10. Although most of the province of Kathiawar is covered by Deccan trap, the coastal margins include belts of Tertiary sediments that overlie the Deccan, and these sediments are probably present on the shelf off the Kathiawar coast. Schroeder (1961) has suggested the probable presence of a tear fault along the southeast coast of Kathiawar that extends across the Gulf of Cambay into peninsular India.

The shelf off the Gulf of Cambay is extremely broad, being about 190 miles at its widest. The shelf surface is remarkably flat, for over a broad expanse as much as 90 miles wide and 250 miles long the outer belt of the shelf lies at a depth of about 270 feet. Southtrending banks lie within the Gulf of Cambay, but south of these the shelf is a wide featureless plain. The present Gulf lies within a trough of a sea that trended northward to the Himalayas during Eocene time, and Eocene marine beds and younger Tertiary formations are exposed at places along each side of the Gulf. Ghosh (1959) notes that a well drilled near the port of Cambay contained about 7,000 feet of sediments above the Deccan trap, and these sediments are expected to thicken southward in the trough under the Gulf.

The coast from Bombay southward is relatively straight but is indented at many places by small estuaries that were formed at the mouths of the short streams whose headwaters lie in the high plateau of the Western Ghats. Southwest of Bombay the continental shelf is 140 miles wide. It is exceedingly even and flat lying, as indicated by the name "fifty fathoms flat" given one broad flat area. (See fig. 10.) To the southeast the shelf narrows gradually to about 35 miles wide at latitude $10^{\circ} \mathrm{N}$. The geology of the western Indian coast varies from north to south. In the Bombay area the rocks consist largely of lavas that have $r$ isen along a fracture. These rocks are more acidic than the basalts of the Deccan trap, and their form at some places suggests volcanic cones. Farther south the more normal basalts of the Deccan type are present, resting upon metamorphic and igneous rocks of the Archean platform of peninsular India. Narrow belts of Tertiary, Pleistocene, and Recent sediments are present along the southern part of the coast.

The geology of the continental shelf south of the Gulf of Cambay is not known. Where ship soundings indicate that rocky bottom is present on the shelf, the bottom may consist largely of corals. At some places on the continental shelf and slope, indurated Tertiary sands may be present above basalts of the Deccan type. Figure 11 shows the conjectured former extent of the Deccan trap, extrapolated seaward and into southern peninsular India by the present writers from results of studies by Crookshank (1952) and Krishnan (1956). Krishnan comments on the remarkable straightness of the continental shelf along western peninsular India down to Cape Comorin and attributes this characteristic to downfaulting to the west, possibly during early or middle Miocene time. A thick sequence of upper Tertiary and Recent sediments may be present near the shelf border south of the Gulf of Cambay if this Indian coast was faulted in Miocene time.

The shelf off southern India near Cape Comorin is as much as 60 miles wide and slopes gently seaward to merge into the low dip of the continental slope. It may consist largely of Archean rocks, with a thin cover of Tertiary sediments. Canyons may be present on the continental slope, but soundings on the present charts are insufficient to determine their location and outline.

From Cape Comorin the shelf trends northeastward along the Gulf of Mannar to the island of Pamban (fig. 12) and apparently narrows to as little as 15 miles. Pamban Island is connected to Mannar Island off Ceylon by a very shallow threshold known as Adams Bridge, and chart soundings show that a lowering of the ocean by as little as 12 feet would connect India with Ceylon. Krishnan (1956) refers to a large part of the Gulf of Mannar and Palk Strait as being very shallow and apparently submerged only in recent geologic time. Sediments of Tertiary age that border the Archean platform of India coastward through Palk Strait have their counterpart across the strait along the northwest coast of Ceylon. Undoubtedly India and Ceylon were joined during a part of the Tertiary and during the Pleistocene.

The apparent straightness of the continental shelf for about 140 miles south of Mannar Island along west ern Ceylon suggests that the shelf here is marked by a fault scarp. The shelf around Ceylon generally is narrow, but it is indented at some places by what are probably the heads of canyons that lie upon the slope. It probably consists predominantly of metamorphic and igneous rock.

From about $9^{\circ} 30^{\prime} \mathrm{N}$. lat. the continental shelf turns northward and widens to as much as 40 miles east of Point Pedro at the northern tip of Ceylon, then narrows along the east coast of India to about 15 miles a short distance south of Pondichery. Along this part of India the shelf, like the coast, probably contains Cretaceous and Tertiary rocks covered by Pleistocene and Recent sediments. Ghosh (1959) indicates that this coastal area contains more than 8,000 feet of sediments and that the shelf here probably contains an extension of marine Cretaceous and Tertiary rocks present inland.

The shelf widens to 30 miles between Pondichery and Madras, possibly because currents that flowed (Continued on p. 20.) 


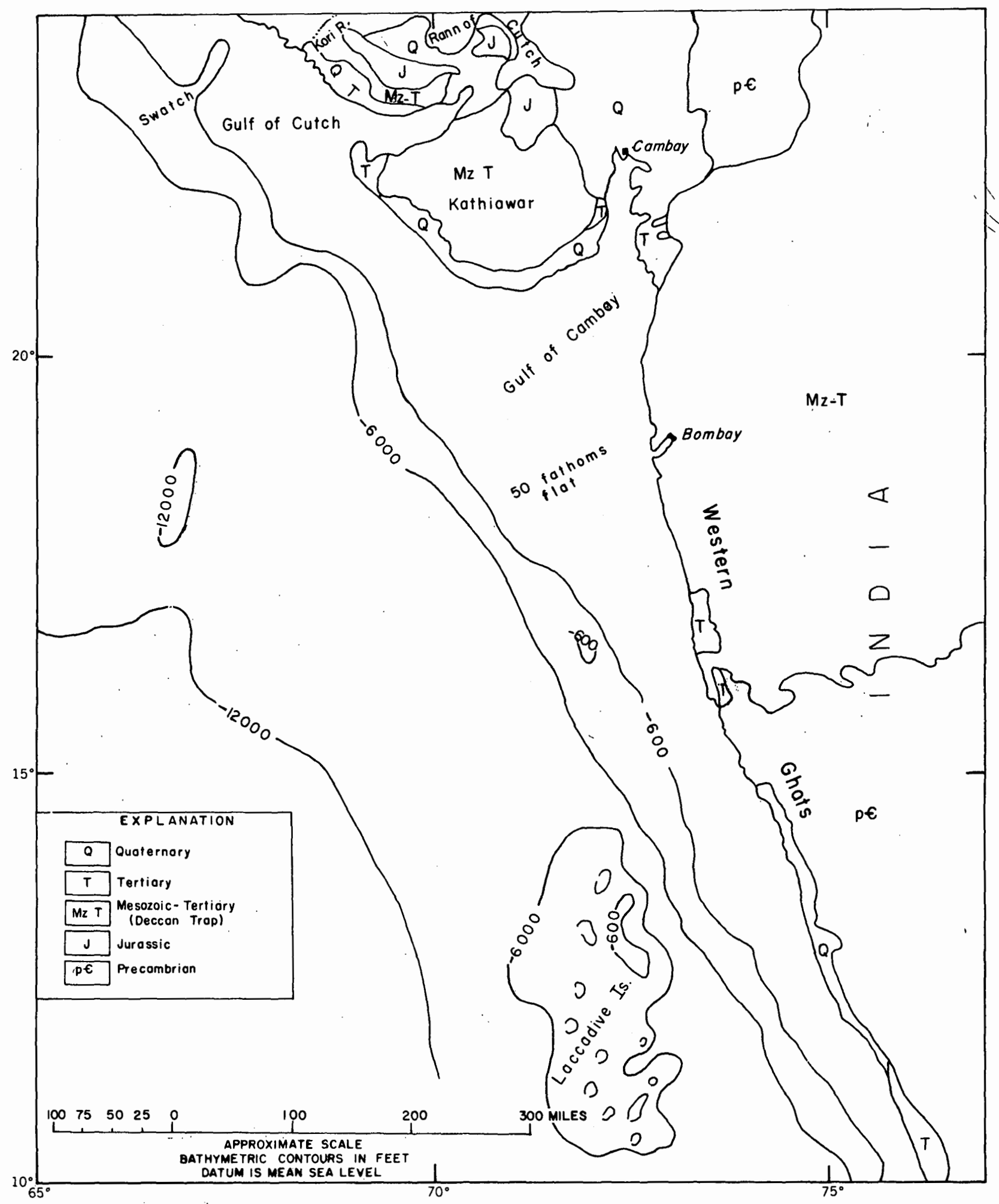

Figure 10.--Diagram showing features of the continental shelf off western India 


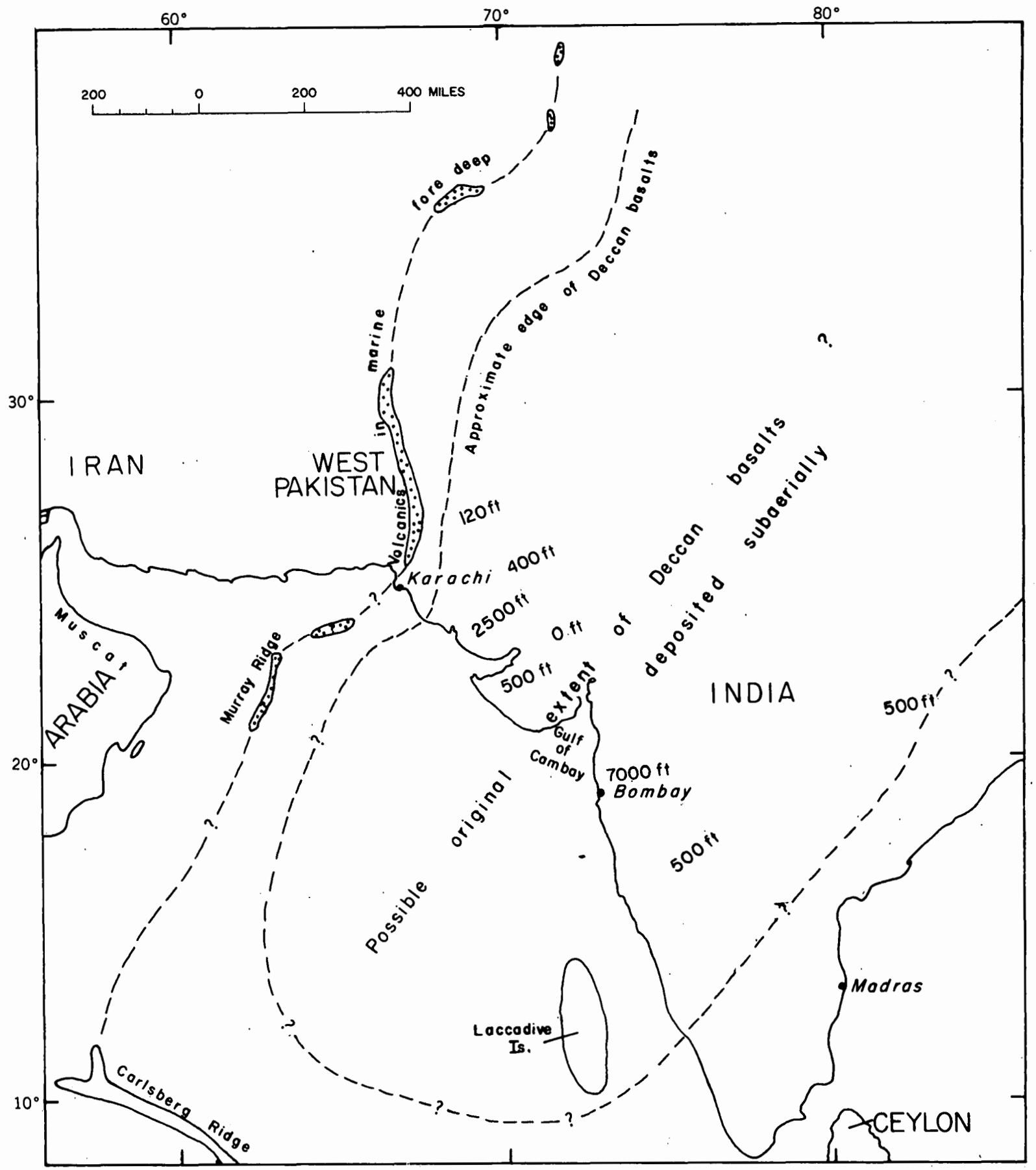

Figure 11.--Diagram showing possible original offshore extent of the Deccan basalts of Late Cretaceous and early Tertiary age.

The western edge of the Deccan basalts is drawn from the description of their approximate position in West Pakistan by Crookshank (1952). The belt of igneous rocks to the west of the Deccan basalts is believed by him to have been extruded into marine waters in a foredeep. He suggests possible continuation of this igneous belt southwestward under the Arabian Sea to Muscat. On the present diagram, however, this belt has been tentatively connected with the Murray Ridge and questionably with the Carlsberg Ridge, subsea features. which have been described by Wiseman and Sewell (1937). The combined thicknesses of basalt flows indicated on the diagram from Bombay northwestward are based on descriptions by Crookshank.

Krishnan (1956; p. 77) has conjectured that the Deccan basalts may have extended some distance west of Bombay. Apparently, normal faulting that occurred along the west coast of India during midMiocene or later time has dropped this part of the basalts beneath the sea. The present writers have drawn the seaward limit of the Deccan basalts east of the Murray Ridge and north of the Carlsberg Ridge. They have conjectured also that the positive anomalies of the Laccadive islands may indicate a center of flow in that area. Krishnan (1956, p. 35) notes that "A zone of positive anomaly runs through the Gulf of Cambay and along the Bombay Coast, which may probably be due to a large thickness of basalt here." 


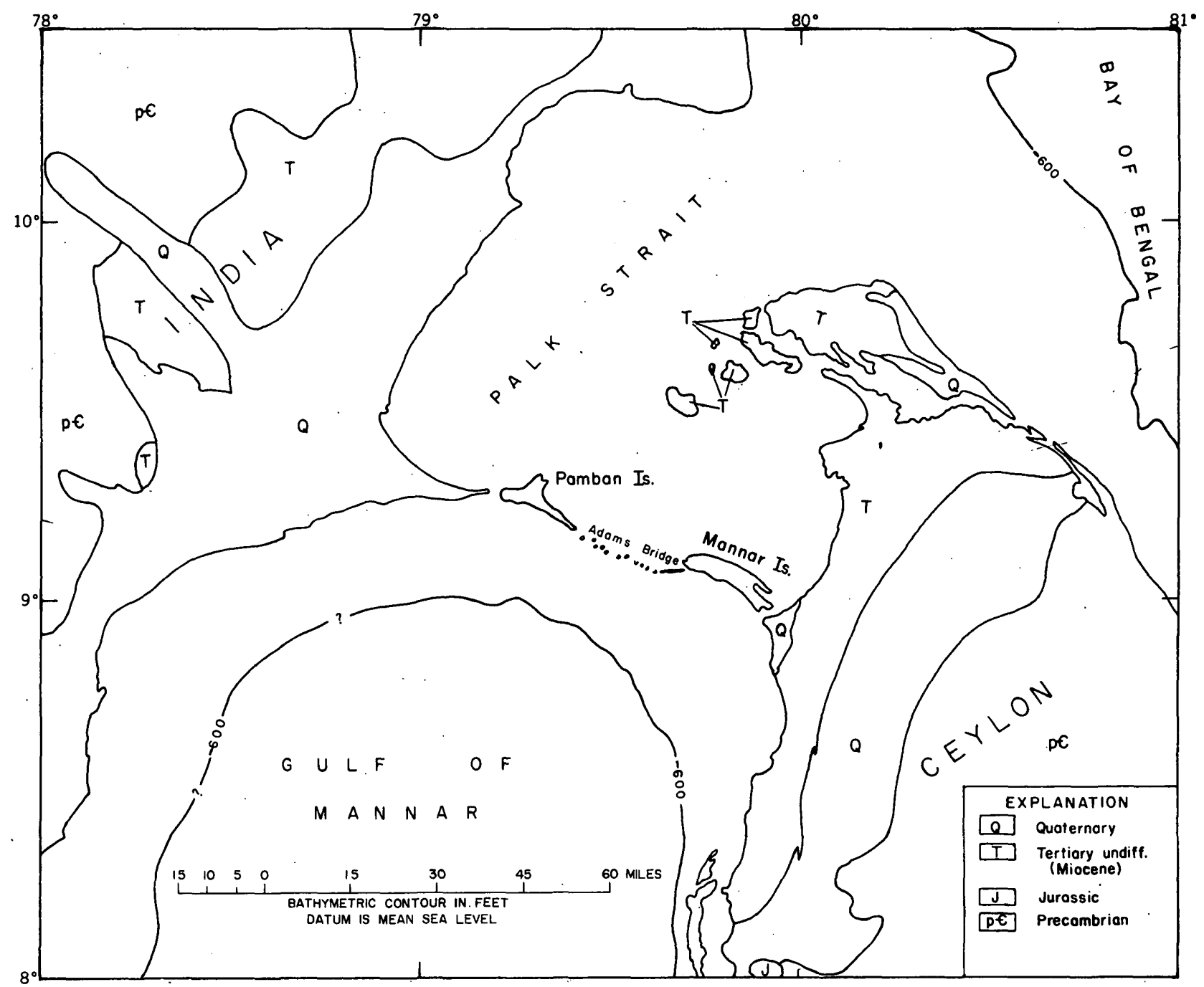

Figure 12.--Diagram showing Gulf of Mannar and Palk Strait and the islands linking southeast India and northwest Ceylon

parallel to the shore have spread sediments from the Palar River, which lies about midway between these points.

Southward from the bay off Cocanada, two streams-Kistna River to the south and Godavari River to the north--have extended their deltas to within about 8 miles of the outer edge of the continental shelf. Embayments on either side of these deltas have been filled by the sediments derived from the deltas and spread by marine currents.

Between Cocanada Bay and False Point to the northeast, the shelf averages about 25 miles in width. The coast here is composed largely of Archean rocks of the Indian shield, bordered by a rim of Pleistocene and Recent sediments. In general, the coastline parallels the trend of the Eastern Ghats, which are said to be faulted on their western side. It is not improbable that the continental shelf or slope may be faulted parallel to the trend of the Ghats. Faulting has not been definitely noted along the coast, but Krishnan (1956) mentions that a series of linear faults seem to have developed in a general northwest trend in Gondwana times along the Godavari valley and along the valley of the Mahanadi River, which opens into the Bay of Bengal near False Point. These faults may reach the coast. Ahmad (1958) considers that the area between the faults was a downwarped block in Gondwana times and later received marine, estuarine, and fresh-water sediments. Rao and La Fond (1954) note that the shelf contains several breaks in slope, which they attribute to longshore currents, tides, and waves.

From False Point eastward to the Ganges River in East Pakistan the coast is covered by a deep mantle of Pleistocene and Recent sediments. The continental shelf here, as would be expected in front of such a large delta, is very broad, being as much as 131 miles wide, and contains many shoal areas.

The Ganges delta and river system are a part of the great Bengal Basin, which has been a sinking trough since Tertiary time and has been affected by faulting from Tertiary to Recent time. The down- 
warping and faulting of the Bengal trough have not been confined to the present land area but presumably extended offshore to the south. The effect of the faulting cannot be noted on the shelf and slope, however, because of a cover of late Tertiary and Pleistocene sediments that is probably thick. Fergusson (1863) indicates that in Recent time the sea stood near the Rajamahal Hills, an area of Jurassic basalt extending south of the Ganges River, and that the delta has built rapidly southward into the gulf.

Ghosh (1959) suggests that the continental shelf off West Bengal likely contains at depth marine Cretaceous and Tertiary rocks that extend southward from the Bengal Basin, which from geophysical surveys and test drilling is estimated to contain as much as 20,000 feet of sediments above a basement of lava flows that may range from Jurassic to Cretaceous in age.

The shelf off the Ganges delta is about 100 miles wide and for much of its width is covered by less than 300 feet of water. A deep, rather flat-bottomed canyon, known as the Swatch of No Ground, extends from the shelf off the Ganges delta southwestward into the Bay of Bengal. From the shelf margin, the floor of the Bay of Bengal slopes gradually southward as far as northern Ceylon, then becomes irregular and is terminated by troughs more than 12,000 feet deep that extend eastward from southern Ceylon to a ridge of apparent north-south trend lying southwest of the Nicobar Islands.

The long Arakan coast on the east side of the Bay of Bengal lies west of a belt of folded rocks known as the Arakan-Yoma. Chhibber (1934) notes that the trend of folding of the rocks in the Arakan coast is parallel to the coastline, and at places where these folds have been invaded by the sea the ridges form long narrow islands or peninsulas, which are commonly cut by a network of estuaries. This type of coast is prevalent between Akyab and Cheduba Island. North of Akyab are areas of relatively flat coast formed by deltas of rivers that flow from the north. From Cheduba Island southward to Cape Negrais the coast is rugged, with high headlands. The continental shelf narrows to about 60 miles near Akyab and to 8 miles off Cheduba Island but maintains a width of about 30 miles from the main island area to Cape Negrais.

A belt of Tertiary sediments extends southeast ward along the Arakan coast to the island of Cheduba, where they in turn are bordered eastward by sediments of Cretaceous age that may continue as far south as Cape Negrais. The shelf probably contains many ridges of Tertiary rocks at the north and of Cretaceous and Tertiary rocks at the south. The islands and peninsulas are an extension of the mainland folds, and the ridges may extend to the edge of the continental shelf under the mask of Pleistocene and Recent sediments. In Cheduba and neighboring islands (Wilson and Metre, 1953) an area of complex structure is present in which even the hardest rocks are sharply folded and the most conspicuous features consist of crescentic outcrops of sandstone. Oil and gas shows in these islands are said to be generally associated with anti- clinal uplifts or strike-faults. South of the main island area to Cape Negrais the shelf probably contains Cretaceous rocks similar to those of the coast. The straightness of the southern part of this coast bordering the high headlands, however, suggests that downwarping or downfaulting may have occurred and that late Tertiary and Recent sediments may lie in troughs oriented north and south, parallel to the coast.

East of Cape Negrais the character of the coast and continental shelf changes abruptly as they enter the area of the Andaman Sea and the Gulf of Martaban. The coast here consists entirely of Pleistocene and Recent sediments that form the broad deltas of the Irrawaddy River and the Pegu and Sittang Rivers to the northeast. The continental shelf formed by the delta of the Irrawaddy lies at extremely shallow depths for much of its width. (See fig. 13.) This shelf may contain a great thickness of sediments, for exploratory wells drilled on the coast within the Irrawaddy delta have encountered as much as 13,000 feet of sediments. Umbgrove (1938) notes that as much as 40,000 feet of Tertiary sediments may be present in "the basin of the Burmese Gulf" in which lies the present course of the Irrawaddy.

The remarkably straight and steep nearly eastwest-trending continental slope at the foot of the Irrawaddy delta is interrupted by a southward bulge which may mark the seaward extension of a volcanic ridge, now buried beneath deltaic sediments, that connects the volcanic chain of Burma with that of Narcondam Island and the volcanic belt of Sumatra. To the west this slope extends to Preparis South Channel, and to the east it terminates abruptly into the southeast-trending slope of the continental shelf off Tenasserim.

The possible course of an ancient river in the southern part of the Gulf of Martaban is shown in figure 13. The southern part of this course appears to lead into the elbow formed by the change of direction of slope from west-east to south. Northward the river course appears to branch into three tributaries, the two east ernmost trending toward the Tenasserim coast and the northernmost possibly connecting with an early course of the Irrawaddy. Possibly this stream system on the continental shelf was formed in Pleistocene time, when much of the present shelf was above water.

The continental shelf is about 120 miles wide west of the Tenasserim coast. The geology of this coast has not been completely mapped, but the geologic map of Krishnan (1956) shows that late Paleozoic rocks lie between undifferentiated crystallines in this area, and Chhibber (1934) notes that some of these crystalline rocks are granite intrusions as late as Tertiary in age. Tertiary sediments present at a few places consist of shales and sandstones with lignitic coal seams.

Southward the shelf decreases in width to 40 miles as it passes along the Mergui Archipelago and to 30 miles off Malaya. The islands of the Mergui Archipelago, similar to those off the Arakan coast, are the remnants of ridges that parallel or extend into ridges 


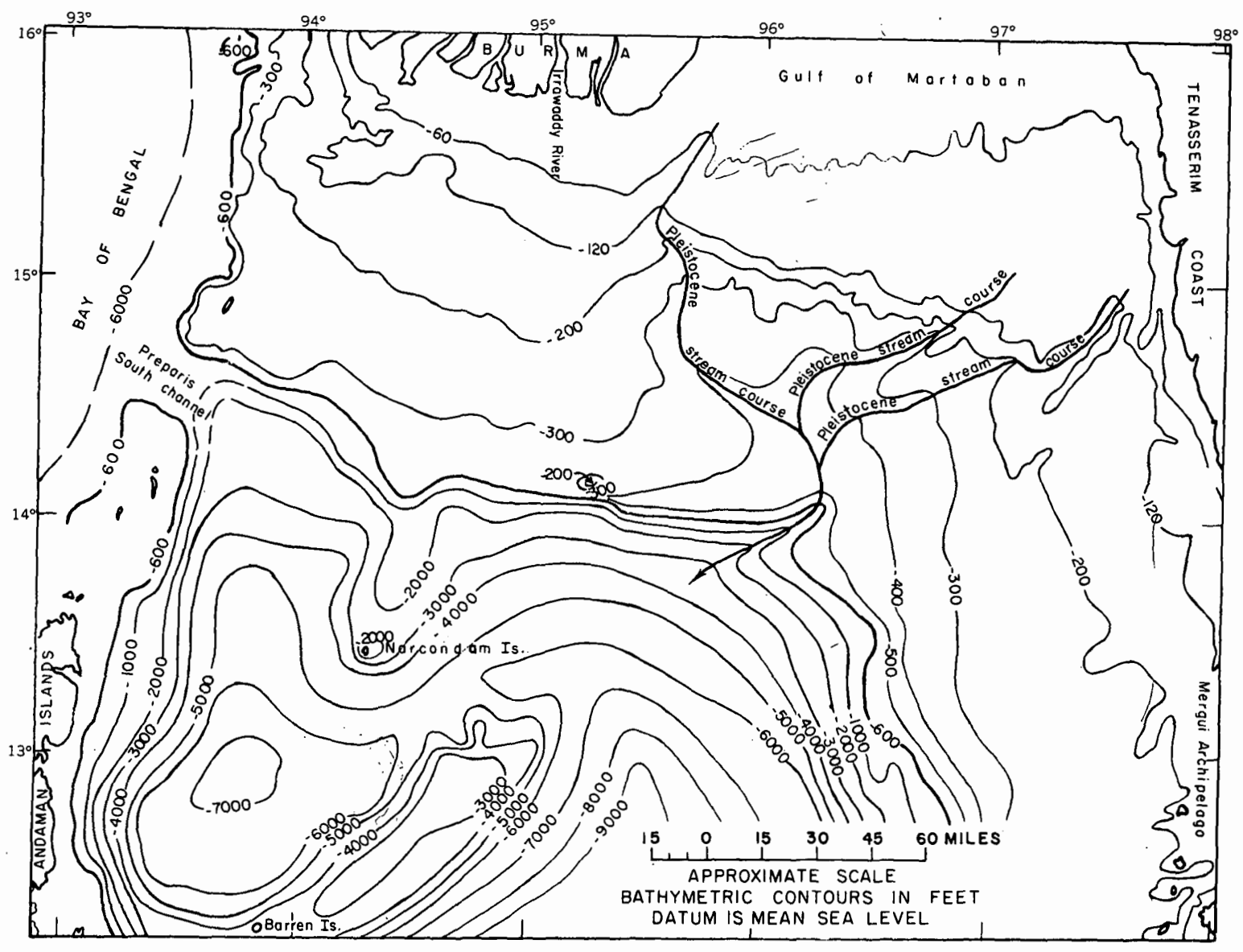

Figure 13.--Diagram showing the broad east-west continental shelf formed by the Irrawaddy delta, location of possible Pleistocene stream courses upon the shelf, and configuration of the deep floor of the northern part of the Andaman Sea. (Bathymetric contours in feet based on soundings in U. S. Navy Hydrographic Office Chart H. O. 1594.)

of the mainland to the north. Many of the islands are granitic, and their softer cover of sediments has been worn down and spread widely as mud flats between the islands. Other islands are the worn-down remnants of upper Paleozoic sediments and now rise only a few feet above the water.

Figure 14 shows the trend of the continental shelf of Malacca Strait around the northwest tip of Sumatra and southeastward past Sumatra and the islands to the west. The shelf around these islands is very narrow. From the north end of Sumatra a trough 3,500 feet deep passes between Sumatra and Simeulu Island as far as Banyak Islands. Deep channels pass between Simeulu Island and Banyak Islands, between Banyak Islands and Nias Island to the south, between Nias and the continental shelf of southwest Sumatra, and extend seaward between Nias and Batu Islands.

The sea south of Sumatra was apparently shallow from middle to late Tertiary time. In late Tertiary time the island arc was upwarped, and the area between the islands and Sumatra was downwarped into a deep inner trough. At the same time an area south of the islands deepened to form an outer trough. The inner trough has apparently become partly filled fromplace to place by clastic Pleistocene and Recent sediments derived from Sumatra and the islands.

The volcanic Barisan Mountain chain dips steeply into the narrow coastal belt of Sumatra, which consists largely of metamorphic rocks but which at several places contains shallow depressions filled with upper Tertiary sediments. Some of the islands west of Suma tra contain a pre-Tertiary core, covered at many places by Tertiary marls, limestones, and sandstones of possible Miocene age. Some Tertiary beds contain fragments of volcanic origin which were probably ejected by volcanoes on the Barisan range. The islands belong to a nonvolcanic belt characterized by Miocene folding.

The continental shelf off southernJava rangesin width between 5 and 12 miles and borders a deep trough that extends eastward to Soemba Island. Mountains border the southern coast of Java except near the central part and the western end, where small embayments contain beds of late Tertiary age.

The shelves around the island of Soemba are apparently narrow. The island is covered largely by Tertiary sediments.

(Continued on p. 24.) 


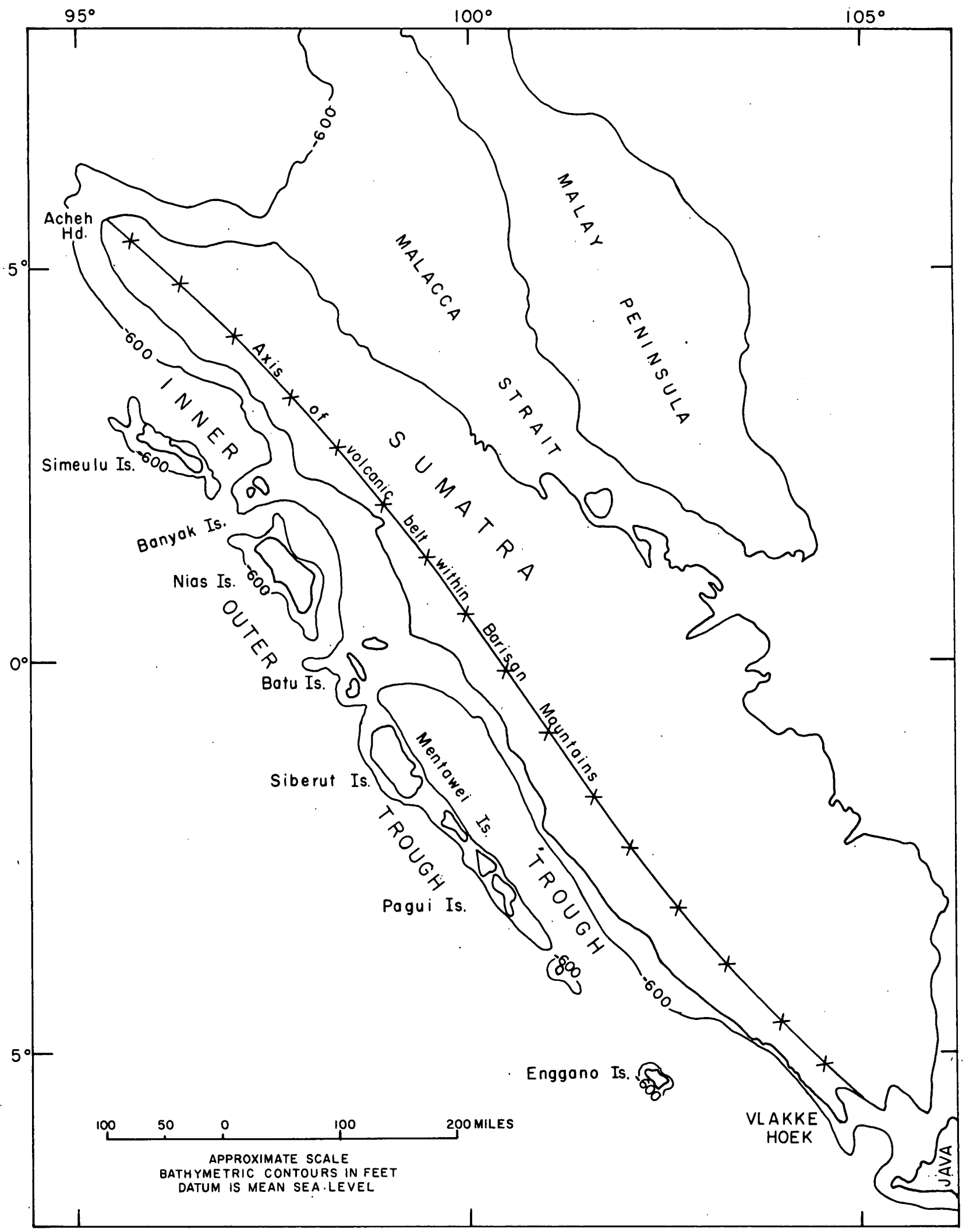

Figure 14.--Outline map of Sumatra and islands to the west, showing trend of the continental shelf and position of inner and outer deep troughs 
The island of Timor has a sinuous coastline and an exceedingly narrow continental shelf that ranges from 1 to 8 miles in width but averages not more than 2 . The steep mountains that lie along the northwestern and southeastern coasts run steeply into deep troughs bordering the island on those sides. Gageonnet and Lemoine (1957a, b, c) state that Permian to Jurassic, Tertiary, and Quaternary deposits are represented in the eastern part of Timor. Major overthrusting in the late Tertiary, formation of simple folds in Pliocene and Pleistocene time, and uplift have been the principal tectonic events there, and displacement due to effects of gravity has been important. Schuppli (1946) indicates that Timor lies in the same structural zone as the islands west of Sumatra and that the main folding in Timor took place in Miocene time as the result of southward-directed tectonic movements.

From their detailed study of the continental shelves of western Australia, Carrigy and Fairbridge (Fair bridge, 1953; Carrigy and Fairbridge, 1955) have been able to show that "a positive relationship exists between the morphology of the continental shelves, the adjacent ocean floor, and the Precambrian basement of the land mass of western Australia." Their classification of the morphology of these shelves is based on the area, width, and declivity of the shelf, inclination of the continental slope, and tectonic consideration of the adjacent ocean floor and continental mass. The deepsea basins off Australia, according to Fairbridge (1955) seem to lie opposite the broad shelves and the continental basins, whereas the deep-sea ridges lie in the same trends as the Precambrian structural "grain" of the mainland. He indicates that from this it may be concluded that the features of the deep-sea floor off western Australia are intimately related to the features of the western Australian shield. He suggests that similar relationships may be observed elsewhere, especially off east Africa.

Carrigy and Fairbridge have divided the shelves of western Australia, from north to south, into the Sahul, Rowley, Dirk Hartog, and Rottnest shelves, separated by rises extending seaward from the continent. (See fig. 15.)

The Sahul shelf is as much as 280 miles wide to the north and about 100 miles wide near its southern boundary. Many reefs and coral islands border the part along the Timor trough; some rise from depths of 1,800 feet. The continental slope here is fairly steep and drops off the shelf to a depth of more than 10,000 feet into the Timor trough.

The coast along the Sahul shelf is extremely irregular. At the north, Bonaparte Gulf makes a broad embayment into the land. From Cape Londonderry southwestward the coast is cut at many places by deep nar row embayments which appear to lie along the "grain" or structural trend of the basement rocks. Islands of the Bonaparte Archipelago lie close to the coast between Cape Londonderry and King Sound. They are fringed by coral reefs but appear to consist largely of basement rocks, which may also form the core of coral banks that lie off the islands.
Pre-Paleozoic rocks occupy the coastal areas along most of the Sahul shelf except for the Bonaparte Gulf area and that part of the Fitzroy basin lying inland from King Sound. In these two basinal areas Paleozoic rocks border much of the coast. Along the western margin of the Bonaparte Gulf basin several thousand feet of marine sediments from Cambrian to Permian age are exposed. Permian rocks are faulted against or overlap Precambrian rocks along the eastern maro gin. Schneeberger (1954) indicates that the basin is a graben which is bounded on the southeast by a major fault system against the Precambrian. He also notes a similarity to the Fitzroy basin in probable draping of Permian beds over basement buried ridges or Devonian reefs. The sediments, which have been faulted and deeply eroded over much of the Bonaparte Gulf basin, probably extend offshore and may be of greater thickness, as the trough of the basin is said to lie within the gulf. On the east side of King Sound, small exposures of Cenozoic rocks within the Fitzroy basin lie coastward of a wide band of Permian beds several thousand feet thick that include marine siltstone, sandstone, and limestone, and fresh-water conglomerate, sandstone, and shale. Gentle folding is said to occur throughout the Permian of the Fitzroy basin. The sedimentary sequence may extend offshore under King Sound, but seaward of that area it may be cut by the strike of basement rocks. The Fitzroy basin has been described (Guppy and others, 1958) as a thick grabenlike wedge of sediments controlled by northwest trending faults on the north and south. The structure on the south, known by some as the Fenton fault but considered by others to be the edge of buried ridges rather than a fault, marks the boundary between the Fitzroy basin or trough to the north and the Canning basin to the south.

The Rowley shelf broadens from Cape Leveque southwestward opposite Eighty Mile Beach to about 150 miles, then narrows to 12 miles at its southern limit off Northwest Cape. The Rowley Shoals, for which this shelf was named, lie seaward of the 600foot shelf line; however, coral reefs are present at places along the edge of this shelf and are associated with some islands nearer the coast. Carrigy and Fairbridge $(1955$, p. 85 ) indicate that the very narrow shelf off Northwest Cape may be "fault controlled."

Scattered islands are present off the coast of Eighty Mile Beach. Southwest of this beach the coastline is irregular, possibly owing in part to the presence of basement rocks under a narrow and thin layer of coastal sediments. Numerous islands are present toward the southern limits of the Rowley shelf; one about 40 miles off the coast is shown on the tectonic map of Australia (Australia Bureau of Mineral Resources, Geology and Geophysics, 1960) to be covered by Tertiary sediments.

Mesozoic sediments of the Canning basin extend to or closely border the coast along the Rowley shelf to about $20^{\circ} 10^{\prime} \mathrm{S} ., 119^{\circ} 20^{\prime} \mathrm{E}$. Because this basin is covered widely by surficial sand and essentially flat Mesozoic sediments that are partly marine and partly continental, the underlying succession and structure

(Continued on p. 26.) 


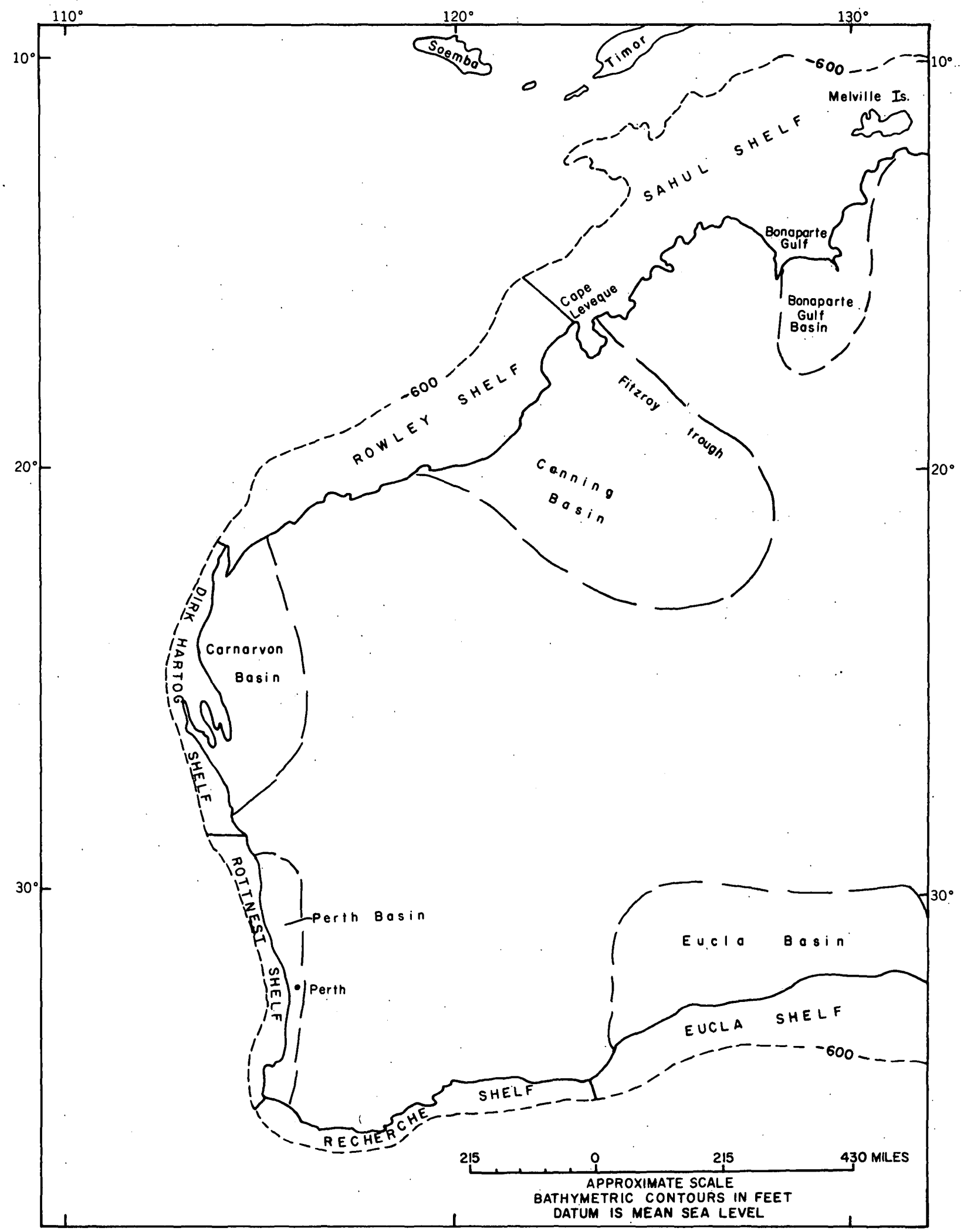

Figure 15,--Diagram showing continental shelves of western Australia separated by continental rises (modified from Carrigy and Fairbridge, 1955) and outlining inland basins (adapted from Teichert, 1958). 
are not well known. The sequence as compared to the Fitzroy basin is believed to be relatively thin and undisturbed, according to Playford and Johnstone (1959).

Teichert (1958) indicates that about 34,000 feet of sediments are present in the basin he designates "the Canning basin," which, however, takes in the Fitzroy basin or trough, and suggests that this sedimentary sequence probably. thickens offshore. At some places within the Fitzroy basin the sedimentary sequence is relatively thin, for a well drilled in 1960 not far from the coast is reported (Rudd, 1961) to have reached Precambrian phyllite at 5,429 feet, after passing through Mesozoic, Permian, and Ordovician sediments. Carrigy and Fairbridge (1955) suggest that the continental shelf opposite the Canning basin is being actively downwarped and that the shelf probably contains an accumulation of sediments since early Permian time. The subsidence of this basin probably is recent, because at present there is no active sedimentation in this area. South of the Canning basin, ancient crystalline rocks lie close to or reach the coast at some places along the Rowley shelf; toward the southern limit of the shelf the coastal sequence is part of that of the Carnarvon basin and consists of Quaternary marine and continental sediments and, along Northwest Cape, Tertiary beds.

The Dirk Hartog shelf, which extends from Northwest Cape to the northern edge of Houtman Rocks at about $28^{\circ} \mathrm{S}$., is narrower than the northern shelves. Its width at the north is only about 24 miles but is as much as 100 miles near Dirk Hartog Island off Shark Bay and 94 miles at the south. The shelf boundary at the south, according to Carrigy and Fairbridge (1955), corresponds approximately with a broad platform, the Abrolhos Rise, and may be related to faulting along the margins of blocks of ancient rocks.

The coast along the Dirk Hartog shelf is irregular. Northwest Cape lies at the head of the high peninsula that borders Exmouth Gulf. Tothe south toward Shark Bay, cliffs border the coast at places. The coast is deeply indented at Shark Bay, which is extremely shallow and which in its southern part is divided by a long peninsula. Westward, Shark Bay is bordered by a chain of islands, of which Dirk Hartog is the largest and highest, reaching an elevation of $608 \mathrm{feet}$. The coast around Shark Bay is low lying and sandy, but to the south, cliffs 300 to 400 feet high border the ocean.

The peninsula that extends southward from Northwest Cape consists of Tertiary limestones and is very gently folded. The Carnarvon basin extends southward from the cape about 450 miles, as far as the Precambrian complex east of Houtman Rocks. Eastward this basin is bordered by the Precambrian shield. Its western edge is said to be submerged under the Indian Ocean. Its sediments include limestone, sandstone, and siltstone ranging in age from Middle Devonian to late Tertiary, with an aggregate thickness. (Teichert, 1958) of about 40,000 feet, which may include 13,000 feet of marine Permian and 11,000 feet of marine Jurassic rocks.

The Rottnest shelf, which extends from Houtman Rocks to the southwest tip of Australia off Cape Leeuwin, is narrow, ranging only from about 30 to 60 miles in width over its total length. Carrigy and Fairbridge (1955, p. 89) suggest that it is a sedimentary feature, 1***moulded by downwarping and faulting (Jutson, 1934) and modified by eustatic changes of sea level which have drowned Pleistocene erosion features***" They suggest that sedimentation has been able to keep pace with the downwarping--1***an hypothesis which is favoured, apart from purely geological data, by the negative isostatic anomalies."

Houtman Rocks, lying about 30 miles off the coast, consist of several groups of small islands surrounded by coral reefs and pinnacles. The coast from Geraldton, east of Houtman Rocks, sweeps southward in sinuous curves with few indentations to Cape Naturaliste at about $33^{\circ} 31^{\prime} \mathrm{S} ., 115^{\circ} \mathrm{E}$. Nearly its full length is bordered by low hills of indurated calcareous sand dunes several hundred feet high. Fringing and barrier reefs are present along the shore at many places. A belt of Archean rocks between Cape Naturaliste and Cape Leeuwin forms a straight coast and rises to 700 feet as a horst which may be faulted along its borders.

The Rottnest shelf over much of its extent is bordered on the mainland by the Perth basin. This basin is described (Playford and Johnstone, 1959) as a long, narrow trough of sediments which may exceed 55,000 feet in thickness, bordered on the east by the structure known as the Darling fault with a throw of 40,000 feet or more. Teichert $(1958$, p. 583) has suggested that this basin has a flexured eastern margin along the Darling scarp, not a faulted one. Details of the sedimentary sequence from place to place are not well known, but in the northern part as much as 30,000 feet of unfossiliferous early Paleozoic or late Proterozoic sediments may. underlie later Paleozoic, Mesozoic, and Tertiary rocks. Permian sediments, as much as 6,000 feet thick in the northern part, include a glacial formation at the base, followed upward by mixed marine and continental beds. Marine Triassic, Jurassic, and Upper Cretaceous, as well as continental Jurassic and Lower Cretaceous sediments occur in parts of the basin. A test well drilled in 1961 about 180 miles northwest of Perth reached a depth of 13,712 feet and is reported (Rudd, 1962) to have ended in basal Mesozoic rocks.

It would appear that the continental shelf and possibly the slope along the Perth basin should contain thick sediments as the seaward continuation of a downwarped or downfaulted area. Several faults lie west of and parallel to the Darling fault. An arclike fault extends onto the shelf both northwest and southeast of Geraldton, with downthrow to the west. South of Geraldton a north-south fault is conjectured to be present under Pleistocene sediments along the coastal belt and extending offshore to the south. 
The coast of southwestern Australia from Cape Leeuwin eastward to Israelite Bay at about $123^{\circ} 50^{\prime} \mathrm{E}$. is extremely irregular, containing many small embayments bordered by peninsulas that are mainly high rocky headlands. The bordering shelf, known as the Recherche shelf from the Recherche Archipelago that lies upon its eastern part, is 20 to 56 miles wide and lies at relatively shallow water depths. The sea floor beyond the shelf drops sharply to 6,000 feet or more, which suggests that downfaulting has occurred. The islands of the Recherche Archipelagor ise abruptly from a base about 180 feet deep. The coast also rises abruptly to heights of several hundred feet and inland is bordered closely by hills as much as 1,000 feet high.

The rocks along this coast consist mainly of Archean granites and gneisses. Some Mesozoic sediments are probably present, but the small patches of Mesozoic rocks exposed under Pleistocene deposits near the coast in the area between Cape Leeuwin and $115^{\circ} 57^{\prime} \mathrm{E}$. are basalts. Small exposures of Tertiary deposits that touch the coast at some places east of 1179 -are probably largely thin marine deposits, possibly 200 feet thick according to Teichert (1947, p. 55). Two large faults parallel the coast, the longer one at the south extending from $116^{\circ} 10^{\prime} \mathrm{E}$. to the sea at $119^{\circ} 50^{\prime} \mathrm{E}$. In a general way these faults parallel the continental shelf also. Similarly trending faults may be present between the coast and the outer edge of the continental shelf.

The coast eastward from Israelite Bay to $132^{\circ} 50^{\prime} \mathrm{E}$. is sinuous in outline but with few indentations. Cliffs as high as 260 feet border the sea, but at some places low sandy areas or high sand ridges arepresent. The bordering shelf, known as the Eucla shelf from the Eucla sedimentary basin that lies on the landward side, ranges from 60 to 120 miles in width but is widest in the central part. The shelf lies at shallow depth close to shore, but generally within a distance of 2 miles from shore it reaches a depth of 60 feet or more and then dips gradually seaward to the continental slope: The slope drops in a series-of terraces to a depth of 18,000 feet in a distance of 170 miles.

The Eucla basin is shallow, containing not much more than 2,000 feet of sediments of Mesozoic and Tertiary age. No Mesozoic sediments are exposed, however, for Tertiary'sediments cover the surface of the basin completely. A stratigraphic test drilled along the coast near the center of the basin is reported (Rudd, 1961) to have reached Precambrian granite at 1,714 feet, after passing through Tertiary and Mesozoic sediments. The cliffs along the coast consist mostly of marine limestones, but inland these are intercalated with continental deposits. The basement beneath the sediments dips gently toward the southwest, and if this dip is - continued to the outer edge of the continental shelf without interruption, the overlying sediments may attain a thickness of about 3,000 feet. Faulting is not known to be present on the coast or continental shelf. The edge of the shelf may be a fault scarp, however, or several faults may be present on the slope that leads down to the sea floor of the South Australian basin, a relatively narrow trench roughly parallel to the south coast of Australia in which depths exceed 18,000 feet.

The coast eastward beyond the Eucla shelf to Cape Otway at about $143^{\circ} 30^{\prime} \mathrm{E}$. long. is extremely irregular, but the bordering continental shelf contains few irregularities. The shelf varies greatly in width, however, being about 130 miles at its widest in the northwest and 16 miles at its narrowest in the southeast.

The geology of this coast varies greatly from place to place. From the eastern edge of the Eucla basin to Spencer Gulf the rocks are gneisses and granites of the basement complex, from Precambrian to early Paleozoic in age. They form the rocky headlands of the coast and probably form the core of the many islands and groups of islands that lie on the continental shelf. The western coast of Spencer Gulf also consists largely of these ancient rocks, except at its southern end, where belts of Tertiary sediments are present. The narrow Yorke peninsula, which separates Spencer Gulf and the Gulf of St. Vincent, consists of Precambrian, Proterozoic, early Paleozoic, Permian, and Tertiary rocks. (See fig. 16.) Normal faulting is present along the western coast of Spencer Gulf, on Yorke peninsula, and along the east coast of the Gulf of St. Vincent, in rocks similar to those of Yorke peninsula. The faults apparently continue under the Gulf of St. Vincent and on Kangaroo Island in dolomites of Cambrian age. The two gulfs are the sites of old lines of weakness in the Precambrian basement. According to Fairbridge (1950) they lie within "early Paleozoic fold belts of the Adelaide" today affected by intense fracturing of the late Tertiary as part of a region known as the Great Shatter Belt, which includes not only the Spencer and Vincent grabens but corresponding horsts such as Kangaroo Island and Yorke peninsula. The present writers conjecture that the faulted embayment extends to the edge of the continental shelf and may contain a considerable thickness of Tertiary and older sediments.

From Kangaroo Island, which consists largely of Cambrian dolomites, the coastline turns northeastward along similar rocks, then turns abruptly southeastward in Tertiary sediments, which are downfaulted against the harder rocks of the mainland. The shore along this concave embayment for about 100 miles is a sand bar enclosing a long narrow lagoon. The few available soundings show depths of 100 feet close to the shore in the northwestern part, whereas depths are considerably shallower along the southeastern part. The continental shelf reaches a width of 120 miles off this coast because of the embayment and not from a change in trend of the shelf margin. The coastal Tertiary rocks apparently lie on basement rocks that form the southwestern rim of the Murray River basin, which dips to the northeast. At some places along this coast the basement lies at sea level and is covered by only thin deposits of Tertiary sediments. A bank southeast of Kangaroo Island and granitic islands south of 


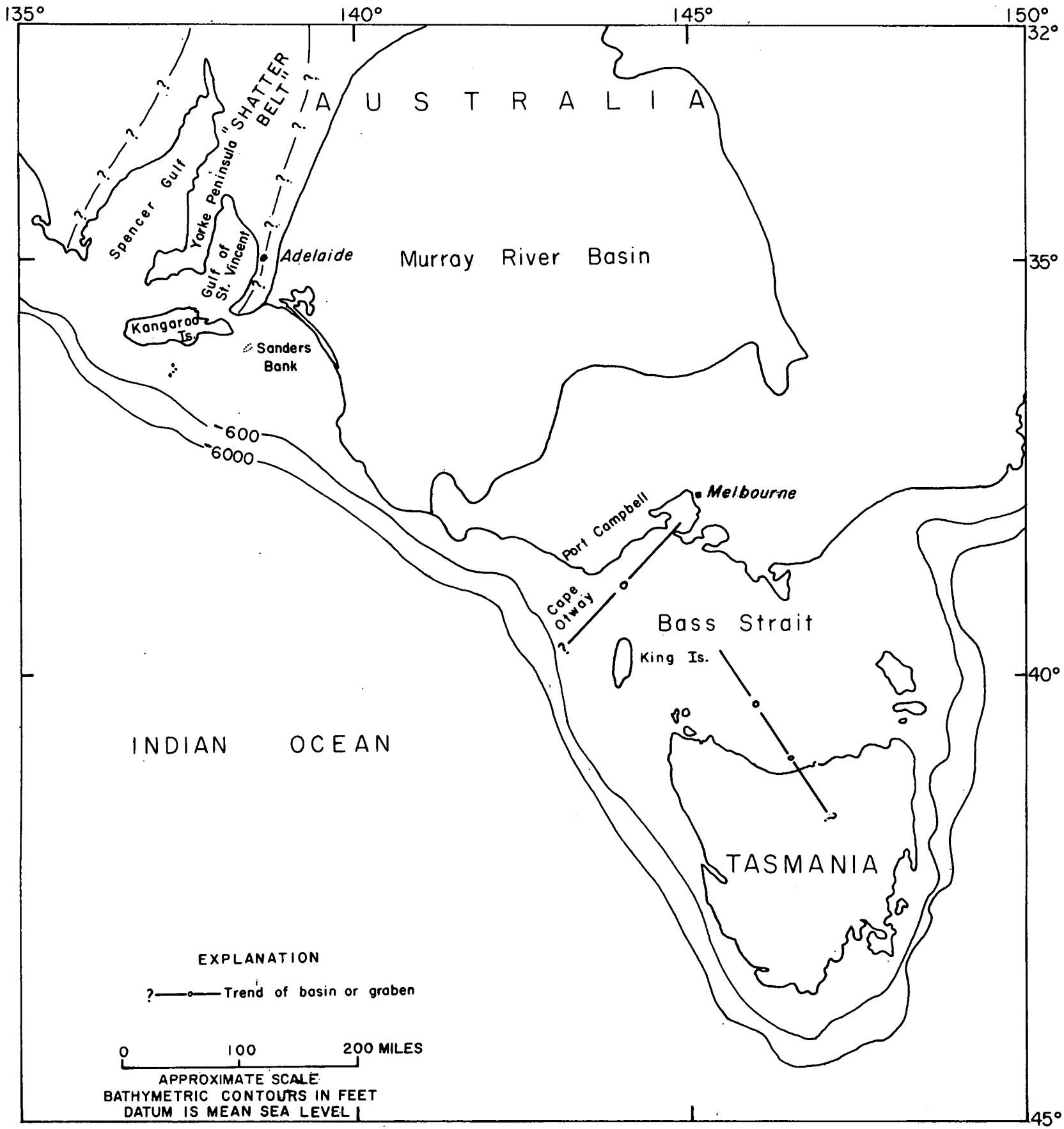

Figure 16.--Diagram showing southeastern Australia and Tasmania and structural features related to the continental shelf

that island suggest that a part of the shelf is composed of basement rocks and that the sediments may be thin. Southeastward a very considerable thickness of Tertiary sediments may be present on the shelf, for Gentilli and Fairbridge (in Lobeck, 1951) note that distinct limestone ridges are present on the shelf parallel to ridges on the mainland.

For the most part, the coast from the southeast end of the concave embayment toward Cape Otway is low and bordered by sand dunes or low terraces, but terraced hills near the cape rise as much as
500 feet. The continental shelf along this coast ranges in width from 16 miles near the north end to about 60 miles at Cape Otway. The coast consists of Tertiary sedimentary rocks and some volcanics, except near Cape Otway, where Mesozoic deposits are present. The Tertiary beds along the northwestern part of the coast may reach a thickness of 10,000 feet. This part of the coast contains several normal faults downthrown toward the sea, and the narrow shelf here is probably faulted also. Between the faulted area on the coast and the Mesozoic rocks at Cape Otway, contours on the basement rock, as 
shown by the tectonic map of Australia (Australia Bureau of Mineral Resources, Geology and Geophysics, 1960), indicate that the basement is downwarped in a narrow syncline that plunges southwestward under the shelf at depths greater than $-5,000$ feet.

A well drilled in 1960 in the Port Campbell area (fig. 16) is reported (Rudd, 1961) to have been abandoned at a depth of 8,846 feet, after passing through Tertiary and some Cretaceous sediments. According to Rudd, this and other drilling in the area has 1***established the presence of a relatively thick section (5,000-7,000 ft.) of Mesozoic sediments ***"

Australia is separated from Tasmania by Bass Strait, which is about 320 miles long and 130 miles wide at its narrowest point. The strait is shallow, depths in excess of 300 feet being rare, and it is flanked on the east and west by numerous islands. Islands are not present, however, between King Island of the western group and Cape Otway in Australia, and a syncline that plunges southwestward on the mainland from Melbourne may continue through the strait and to the edge of the continental shelf. The central part of Bass Strait is a downwarped block or graben that probably trends northwestward as a continuation of a basinlike structure of northern Tasmania. According to Boutakoff $(19.55$, p. 43$)$ the strait was formed in the late Tertiary. The presence of numerous small islands between King Island and the western peninsula of Tasmania indicates that at one time these two areas were connected.

The continental shelf from northwestern Tasmania southeastward along the western margin of the island is somewhat irregular, extending seaward at some places. In the southwestern part the shelf is cut by a canyon, and probably other canyons are present along the western coast, though soundings are insufficient to show this.

The coast of western Tasmania is irregular in outline, containing numerous small embayments surrounded by hills in the southern part but including some stretches of flat land in the northern part. The rocks of western Tasmania consist of a complex of metamorphic rocks of Proterozoic age, overlain at places by Cambrian to Devonian pyroclastic rocks, sandstone, shale, limestone, and conglomerate cut by ultrabasic and acid igneous intrusives. King Island is composed mainly of rocks similar to those of northwestern Tasmania, but belts of Tertiary sediments are present on its western side. In southwestern Tasmania, Tertiary and Recent sediments are present in a narrow belt along the coast at $42^{\circ} 10^{\prime} \mathrm{S}$., $145^{\circ} 20^{\prime} \mathrm{E}$. All of the older sequence has been folded, and Paleozoic rocks contain numerous normal faults.

Several authors have referred to the tectonic movements that have affected coastal margins and the bor dering offshore of both southern Australia and Tasmania. For example, Glaessner (1953-54), in discussing the possible relationship of the Tertiary basins of southern Australia to the continental shelf and the ocean floor, suggests that these basins show the effects of some folding and that in some areas intense fracturing has followed old lines of weakness. He concludes that apparently only the "hinge belt" of the basin area is visible and that the greater part of it lies under the waters of the ocean. Fairbridge (1950) states that the submarine soundings along the south coast of Australia indicate such steep slopes that they suggest faulted origin, and his diagram on geomorphologic evolution of Australia shows inferred faults along the continental shelf in the western part of southern Australia, along the Murray River basin, and across Bass Strait to Tasmania.

\section{HOW FAULTING HAS AFFECTED THE CON- TINENTAL MARGINS AND OCEAN FLOOR}

Displacement of the margins of the continents around the Indian Ocean by faulting has been recurrent through most of geologic time. Along the western borders of the ocean, block faulting has been prevalent. Here the most intense faulting probably took place in Late Cretaceous time, and a great thickness of Eocene sediments accumulated at many places along fault scarps off the continental shelves as the seaward blocks sank gradually into the ocean. Marked faulting occurred during the Miocene and also in the Pleistocene in many places around the borders of the Indian Ocean. Some island chains that lie in the western Indian Ocean are the surface expression of great $r$ idges that $r$ ise high above the ocean floor. The Seychelles Islands lying on one such ridge may be the remnant of a continental mass similar to that of Madagascar. At other places on these submarine ridges, shoals mark former islands, now sunk below the surface, or they mark areas that have not $r$ isen quite to the surface of the sea. The ridge upon which lie the Maldives and Chagos groups may indicate the eastern limit of marked block faulting, for east of this ridge the floor of the Indian Ocean extends as a relatively flat featureless plain to the Java Trough and the continental slope off western Australia.

Upwarping of the faulted blocks may have connected large areas of the continents from time to time. Whether the blocks were connected seaward across the Indian Ocean from Africa to Australia as part of Gondwanaland, a postulated continental landmass believed by some to have existed to the Cretaceous or possibly into the Tertiary, can be only a conjecture, based on geologic data presently available.

Teichert (1958, p. 586) does not concur with many geologists that Australia was a part of this ancient landmass, if one existed, for he states, "As regards Australia, it seems that its paleogeography, its structure and the history of its life can be satisfactorily explained without the Gondwanaland hypothesis and on the assumption that Australia was always a separate continent."

Perhaps no vast landmass connected Africa to Aus tralia or existed as a single continent at a single time. Within the area of the western Indian Ocean, however, there apparently were distinct land connections at places between India, Madagascar, and Africa. These may have been a series of islandlike upwarped blocks produced by faulting on the sea floor and landward 
margins. Upwarped blocks in the ocean, joined at places to the continents, may have formed land bridges, whereas downwarped blocks marginal to the continents became sites of deposition, which, especially in the Tertiary, received great thickness of sediments.

The rejuvenation, in Tertiary time, of faults bordering the continental shelves by the upwarping of the shield blocks and the downwarping of the marginal ocean blocks must have increased the amounts of sediment deposited upon the slope and sea floor in the long erosion period that followed these structural movements. If great thicknesses of unconsolidated sediments accumulated along steep fault scarps at the outer margin of the continental shelves, as was probable in Eocene time, the sediments would tend to slide, thus forming turbidity currents, which would spread the sediments widely on the sea floor.

The deposition of thick sediments on the continental slope depends in part upon the length of time between periods of rejuvenation. If much relatively recent faulting occurred during the brief time, geologically, since the Pliocene, then the accumulation of thick sequences of post-Pliocene sediments has occurred mainly at the mouths of such great deltas as those of the Indus, Ganges, and Irrawaddy rivers, whereas the volumes of post-Pliocene deposits off the mouths of numerous small rivers and along the continental slopes has been comparatively slight.

The geological literature contains an impressive number of references to structural movements during Pliocene and post-Pliocene times in lands bordering the Indian Ocean. In North Africa, Pliocene and probable Pleistocene uplifts have taken place that apparently rejuvenated older folds and fractures. Considerable coastal movement is thought to have occurred in Tanganyika during the Pliocene and Pleistocene. Dixey (1956, p. 5) writes of the African Rift system, with special reference to the Nyasa, Rukwa, and Tanganyika rifts: "A considerable part of the $r$ ift system originated in two main series of fractures***." The second, which is post-Pliocene in age, followed very closely the lines of the earlier fractures, and "***has continued locally even into modern times."

According to Swartz and Arden (1960), earth movements in the Red Sea area formed a V-shaped trough between the Horn of Africa and the Arabian shelf sometime during the Pliocene and Pleistocene Epochs. Dixey $(1956$, p. 33) indicates that main plateau-forming Gulf of Aden faulting began in about the Miocene, but that faulting continued at intervals into the Pliocene and probably in Recent times.

Activity along the northeast-southwest structural trend in the Middle East is expressed in Recent coast line alinements in southern Arabia and Trucial Oman (Henson, 1951; p. 126).

According to Wadia (1944,p. 24) the "1***whole of the north border of the Arabian Sea is*** surrounded by a series of steep fractures believed to be of Pliocene or even later age."
Morgan and McIntire (1959, p. 319) in mapping the Quaternary geology of the Bengal basin found that block faulting and echelon faulting have so disturbed the topography of the Pleistocene that correlation of terraces is difficult. They indicate that faulting and structural uplift have continued into the Recent.

Krishnan (1956, p. 542) states "The Arakan coast [of Burma] as well as the islands of the Andaman and Nicobar group have undergone submergence in the Pleistocene and Recent times." He also notes (p. 77) that the west Tenasserim coast of Burma is moderately faulted, "***having suffered a slight submergence during geologically recent times."

Umbgrove (1938, p. 67) notes:

"The origin of two 'geanticlines' (Barisan and the series of islands west of Sumatra) and their separation by a fairly deep sea basin should ... . have happened during the most recent times, in the postPliocene (simultaneously with the latest phase in the elevation of the Arakan Yoma). This representation stands a good chance of agreeing with reality."

Kuenen (1950, p. 193) has noted the elevations of Pliocene-Pleistocene reefs in the southern Moluccas and has indicated that on Timor the heights above sea level are more than 4,000 feet $(1,283 \mathrm{~m})$.

Of Australia, Clarke, Prider, and Teichert (1955, p. 285) have stated:

"In Pliocene and later times most of the continent was raised epeirogenically, the greatest amount of uplift being in the south and east. As is usual in such movements, some parts gave way under the tensional stress of the uplift and sank, forming rift valleys. It was probably at this time that the Darling Fault (or perhaps monocline) and the Great Shatter Zone of South Australia were formed. The uplift, which in eastern Australia amounted to 4,000 to 5,000 feet and in west Australia must have been in the neighbourhood of 2,000 feet, has been responsible for the formation of the existing mountains of the continent, which therefore are block mountains, not fold mountains."

In their descriptions of the geology of South Australia, Glaessner and Parkin (1958, p. 141-142) note that a revival of tectonic activity, which was characteristic of the Tertiary, culminated in major uplift and faulting in late Pliocene to early Pleistocene times. During those times the seas retreated from the St. Vincent and Murray basin areas, and older and newer peneplains were differentially uplifted. Also, broad doming. occurred over much of the area of the former Adelaide geosyncline.

Some of the islands of the western Indian Ocean seem to have been affected mainly by upwarp in recent times, as noted by Reed (1949) and others in the following:

Seychelles.--A recent elevation of more than 200 feet is suggested by the existence of some inland cliffs. 
Mauritius.--Raised coral reefs 40 feet above sea level in the southern part of the island and only 12 feet in the northern part indicate unequal uplift of the island in recent times.

Rodriguez.--Some limestone patches found at an elevation of about 500 feet indicate uplift within recent times.

Aldabra.--Corals are elevated 20 to 80 feet above sea level.

Chagos archipelago.--A rise of 5 to 35 feet is indicated by dead coral reefs.

Maldive group.--Intermittent uplift is indicated by raised beaches and dead coral reefs.

Cosmoledo group, Aldabra Island, Farquahar group.--Many of the islands are undercut, suggesting recent elevation.

From the foregoing it appears that the Indian Ocean and bordering land areas have been very active tectonically from late Pliocene to Recent time. The present writers believe that a zone at least 300 to 400 miles wide, bordering the shield areas of the Indian Ocean, had a long history, from Precambrian to Recent, of structural movements in which large crustal blocks were upwarped or downwarped. They conclude that this zone has been as active tectonically in the geologically brief time from late Pliocene to Recent as in any equivalent length of time during past geologic periods. As the Tertiary had a much greater time span than that of the late Pliocene to Recent, the writers assume that vast areas of the Indian Ocean floor may contain only a thin deposit of terrestrial sediments of Pliocene or younger age, overlying much thicker Eocene and possibly Miocene sediments of terrestrial origin.

The geology of the continental shelves in the present report has been inferred from that of the bordering coasts. Seaward, however, geological information is sparse, and the relationship of the geology of the continental slope to the sea floor is largely unknown. The geology of this marginal belt between the rocks of the continent and those of the sea floor has long been a subject of speculation. Future oceanographic research should include a survey of the continental slopes and shelves by sonic profiles and sonoprobe, by geophysical means, and by dredging for rock samples, not only as an aid to a better understanding of the features of the slopes and shelves but as a sound framework from which to project their geology to the floor of the marginal deeps.

\section{REFERENCES CITED}

Agocs, W. B., Isaacs, K., Hartman, R. R., 1958, Airborne magnetometer profile from Johannesburg to Delhi and its interpretation and geologic correlation: Internat. Geol. Cong., 20th, Mexico City, 1956, sec. 9 , v. 2, p. 315-325.

Ahmad, F., 1958, A preliminary note on the possibility of finding concealed Barakar coalfields in India:
Jour. Mines, Metals and Fuels [Calcutta], v. 7, no. 10, p. $8-13$.

Association des Services Géologiques Africains, 1958, Esquisse structurale provisoire de l'Afrique: scale $1: 10,000,000$.

Australia Bureau of Mineral Resources, Geology and Geophysics, 1960, Tectonic map of Australia: scale $1: 2,534,400$.

Besairie, Henri, 1954, Carte tectonique de Madagascar: scale 1:3,500,000, Madagascar, Service Géologique [Tananarive].

Bettencourt Dias, M., 1956, Esbôco tectónico de Moçambique 1:3,000,000: notícia explicativa: Mozambique Serviços de Indústria e Geologia Bol. no. $18,34 \mathrm{p}$.

Boutakoff, N.,. 1955, A new approach to petroleum. geology and oil possibilities in Gippsland: Mining and Geol. Jour. [Australia], v. 5, no. 4-5; p. 39-57.

Carrigy, M. A., and.Fairbridge, R. W., 1955, Recent sedimentation, physiography and structure of the continental shelves of western Australia: Royal Soc. Western Australia Jour., v. 38, p. 65-95.

Chhibber, H. L., 1934, The geology of Burma: London, Macmillan, $538 \mathrm{p}$.

Clarke, E. de C., Prider, R. T, and Teichert, Curt, 1955, Elements of geology for Western Australian students: Crawley, Univ. Western Australia Textbooks Board, $300 \mathrm{p}$.

Clift, W. O., 1956, Sedimentary history of the Ogaden district, Ethiopia: Internat. Geol. Cong., 20th, Mexico City, 1956, Symposium sobre yacimientos de petroleo y gas, v. 1, p. 89-112.

Cloos, Hans, 1948, Ground blocks of the continents and ocean bottoms [summ.]: Nature, v. 161, no 4080 , p. $71-72$.

Commission de la Carte Géologique Internationale de l'Afrique (International Geological Congress, 18th, London, 1948), 1952, Carte géologique internationale de l'Afrique: sheet no. 6, scale 1:5,000,000.

Crookshank, H., 1952, A note on the western margin of Gondwanaland: Internat. Geol. Cong., 19th, Algiers, 1952, Symposium sur les series de Gondwana, p. 175-180.

Dixey, Frank, 1956, The East African rift system: Colonial Geology and Mineral Resources Supp. Ser., No. 1, $71 \mathrm{p}$.

1959, Vertical tectonics in the East African rift zone: Internat. Geol. Cong., 20th, Mexico City, 1956, Asoc. Servicios Geol. Africanos, Actas y Trabajos, p. 359-375.

Du Toit, A. L., 1926, The geology of South Africa: Edinburgh, Oliver and Boyd, $463 \mathrm{p}$. 
Du Toit, A. L., 1937, Our wandering continents: Edinburgh, Oliver and Boyd, 366 p.

Fairbridge, R. W., 1950, Problems of Australian geotectonics: Scope [Western Australia Univ., Sci. Union Jour.], v. 1, no. 5, p. 22-28.

1953, The Sahul shelf, northern Australia: its structure and geological relationships: Royal Soc. Western Australia-Jour., v. 37, p. 1-33.

1955, Some bathymetric and geotectonic features of the eastern part of the Indian Ocean: Deep-Sea Research, v. 2, p. 161-171.

Farquharson, W. I., 1935-36, Topography, with an appendix on magnetic observations, in The John Murray Expedition 1933-34: Sci. Repts., v. 1, no. 2 , p. 7.-61, London, British Museum (Natural History).

Fergusson, James, 1863, On recent changes in the delta of the Ganges: Geol. Soc. London Quart. Jour., v. 19, p. $321-354$.

Gageonnet, Robert, and Lemoine, Marcel, 1957a, Sur la stratigraphie de l'autochtone au Timor portugais: Acad. Sci. [Paris], Comptes Rendus, v. 244, no. 16, p. 2168-2171.

1957b, Composition et subdivisions du complex charrié au Timor portugais: Acad. Sci. [Paris], Comptes Rendus, v. 244, no. 17, p. 22462249.

1957c, Sur l'âge et les modalités des phénomènes de charriage au Timor portugais: Acad. Sci. [Paris], Comptes Rendus, v. 244, no. 19, p. 2407-2410.

Ghosh, A. M. N., 1959, Possible oil-bearing regions of India: World Petroleum Cong., 5th, New York, 1959, Proc., sec. I, p. 1023-1035.

Girdler, R. W., 1958, The relationship of the Red Sea to the East African rift system: Geol. Soc. London Quart. Jour., v. 114, p. 79-105.

Glaessner, M. F., 1953-54, Some problems of Tertiary geology in southern Australia: Royal Soc. New South Wales Jour. and Proc., v. 87-88, pt. 2, p. 31-45.

Glaessner, M. F., and Parkin, L. W., eds., 1958, The geology of South Australia: Geol. Soc. Australia Jour., v. 5, pt. 2, 163 p.

Guppy, D. J., and others, 1958, The geology of the Fitzroy basin, Western Australia: Australia Bur. Mineral Resources, Geology, Geophysics, Bull. 36, $116 \mathrm{p}$.

Henson, F. R. S., 1951, Observations on the geology and petroleum occurrences of the Middle East: World Petroleum Cong., 3d, The Hague, 1951, Proc., sec. I, p. 118-140.
Hills, E. S., 1947, Tectonic patterns in the earth's crust [presidential address, Sec. P, Geography and Oceanography]: Australian and New Zealand Assoc. Adv. Sci., 26th Mtg., Perth, 13 p. [separate].

Hourcq, Victor, 1953, Madagascar, in Illing, V. C., ed. The world's oilfields--the easter $n$ hemisphere (The science of petroleum, v. 6, pt. 1): London, Oxford Univ. Press, p. 167-168.

Jutson, J. T., 1934, The physiography (geomorphology) of Western Australia: 2d ed., Western Australia Geol. Survey, Bull. no. 95, 366 p.

Krenkel, Erich, 1925-38, Geologie Afrikas: Berlin, Gebrüder Borntraeger, 3 v.

Krishnan, M. S., 1956, Geology of India and Burma: 3d ed., Madras, Higginbothams, 555 p.

Kuenen, P. H., 1950, Marine geology: New York, John Wiley, $568 \mathrm{p}$.

Lobeck, A. K., 1951, Physiographic diagram of Australia: scale 1:7,500,000, New York, Geog. Press, Columbia Univ. (accompanied by $6 \mathrm{p}$. of text, by Joseph Gentilli and R. W. Fairbridge).

Morgan, J. P., and McIntire, W. G., 1959, Quaternary geology of the Bengal Basin, East Pakistan and India: Geol. Soc. America Bull., v. 70, no. 3 , p. 319-342.

Mozambique Serviços de Indústria e Geologia, 1956, Esbôco tectónico de Moçambique [Tectonic mạ of Mozambique]: scale 1:3,000,000.

Playford, P. E., and Johnstone, M. H., 1959, Oil exploration in Australia: Am. Assoc. Petroleum Geologists Bull, v. 43, no 2, p. 397-433.

Pulfrey, William, 1956, The search for oil and natural gas in Kenya: Internat. Geol. Cong., 20th, Mexico City, 1956, Symposium sobre yacimientos de petroleo y gas, v. 1, p. 143-149.

Quennell, A. M., 1958, The structure and geomorphic evolution of the Dead Sea rift: Geol. Soc. London Quart. Jour., v. 114, pt. 1, p. 1-24.

Rao, B. K., and La Fond, E. C., 1954, The profile of the continental shelf off Visakhapatnam coast: Andhra Univ. Mem. Oceanography, v. 1 (Andhra Univ. Ser. no. 49), p. 78-85.

Reed, F. R. C., 1949, The geology of the British Empire: London, Edward Arnold, 764 p.

Rudd, E. A., 1962, Petroleum developments in southwest Pacific region during 1961: Am. Assoc. Petroleum Geologists Bull., v. 46, no. 7, p. 12981302. 
Schneeberger, W. F., 1954, Reef prospects lie beneath Bonaparte Gulf basin area: World Oil, v. 139 , no. 6, p. $260,262,264,274$.

Schroeder, J. W., 1961, The oil exploration in India and the discovery of the Anklesvar oil field: Ver. Schweizer. Petroleum-Geologen u. Ingenieure Bull., v. 27, no. 73, p. 31-36.

Schuppli, H. M., 1946, Geology of oil basins of East Indian Archipelago: Am. Assoc. Petroleum Geologists Bull., v. 30; no. 1, p. 1-22.

Shepard, F. P., 1948, Submarine geology: New York, Harper, 348 p.

Swätz, D. H., and Arden, D. D., Jr., 1960, Geologic history of Red Sea area: Am. Assoc. Petroleum Geologists Bull., v. 44, no. 10, p. 1621-1637.

Talwani, Manik, 1962, Gravity measurements on HMS Acheron in South Atlantic and Indian Oceans: Geol. Soc. America Bull., v. 73, no. 9, p. 11711182.

Talwani, Manik, and Worzel, J. L., 1960, Gravity measurements on HMS Acheron in South Atlantic and Indian Oceans [abs.]: Am. Assoc. Petroleum Geologists, Program 1960 Ann. Meetings, p. 219.

Taylor, Hall, 1948a, Sinclair meets transport problems in exploring its Ethiopian concession: Oil and Gas Jour., v. 47, no. 14, p. 43-45.
Taylor, Hall, 1948b, Geology of Ethiopia being developed by Sinclair in exploring concession: Oil and Gas Jour., v. 47, no. 15, p. 48-49, 51 .

1948c, Mesozoic geology of the SomaliEthiopia area [abs.]: Geol. Soc. America Bull., v. 59 , no. 12 , p. 1357.

Teichert, Curt, 1947, Stratigraphy of western Australia: Am. Assoc. Petroleum Geologists Bull., v. 31 , no. 1, p. 1-70.

1958, Australia and Gondwanaland: Geol. Rundschau, v. 47 , no. 2 , p. 562-590.

Umbgrove, J. H. F., 1938, Geological history of the East Indies: Am. Assoc. Petroleum Geologists Bull., v. 22, no. 1, p. 1-70.

Wadia, D. N:, 1944, Geology of India: London, Macmillan, $460 \mathrm{p}$.

Wellington, J. H., 1955, Southern Africa; a geographical study, v. 1, Physical geography: Cambridge, Univ. Press, $528 \mathrm{p}$.

Wilson, G. F., and Metre, W. B., 1953, Assam and Arakan, in Illing, V. C., ed., The world's oilfields--the eastern hemisphere (The science of petroleum, v. 6, pt. 1): London, Oxford Univ. Press, p. 118-123.

Wiseman, J. D. H., and Sewell, R. B. S., 1937, The floor of the Arabian Sea: Geol. Mag., v. 74, p. 219-230. 